Article

\title{
Three-D Mineralogical Mapping of the Kovdor Phoscorite-Carbonatite Complex, NW Russia: II. Sulfides
}

\author{
Gregory Yu. Ivanyuk ${ }^{1,2, *}$, Yakov A. Pakhomovsky ${ }^{1,2}$, Taras L. Panikorovskii ${ }^{1}$ (1), \\ Julia A. Mikhailova ${ }^{1,2}$, Andrei O. Kalashnikov ${ }^{2}{ }^{10}$, Ayya V. Bazai ${ }^{1,2}$, Victor N. Yakovenchuk ${ }^{1,2}$, \\ Nataly G. Konopleva ${ }^{1}$ and Pavel M. Goryainov ${ }^{2}$ \\ 1 Nanomaterials Research Centre of Kola Science Centre, Russian Academy of Sciences, 14 Fersman Street, \\ Apatity 184209, Russia; pakhom@geoksc.apatity.ru (Y.A.P.); taras.panikorovsky@spbu.ru (T.L.P.); \\ ylya_korchak@mail.ru (J.A.M.); bazai@geoksc.apatity.ru (A.V.B.); yakovenchuk@geoksc.apatity.ru (V.N.Y.); \\ konoplyova55@mail.ru (N.G.K.) \\ 2 Geological Institute of Kola Science Centre, Russian Academy of Sciences, 14 Fersman Street, \\ Apatity 184209, Russia; kalashnikov@geoksc.apatity.ru (A.O.K.); pgor@geoksc.apatity.ru (P.M.G.) \\ * Correspondence: g.ivanyuk@gmail.com; Tel.: +7-81555-79531
}

Received: 30 May 2018; Accepted: 5 July 2018; Published: 9 July 2018

\begin{abstract}
The world largest phoscorite-carbonatite complexes of the Kovdor (Russia) and Palabora (South Africa) alkaline-ultrabasic massifs have comparable composition, structure and metallogenic specialization, and can be considered close relatives. Distribution of rock-forming sulfides within the Kovdor phoscorite-carbonatite complex reflects gradual concentric zonation of the pipe: pyrrhotite with exsolution inclusions of pentlandite in marginal (apatite)-forsterite phoscorite, pyrrhotite with exsolution inclusions of cobaltpentlandite in intermediate low-carbonate magnetite-rich phoscorite and chalcopyrite ( \pm pyrrhotite with exsolution inclusions of cobaltpentlandite) in axial carbonate-rich phoscorite and phoscorite-related carbonatite. Chalcopyrite (with relicts of earlier bornite and exsolution inclusions of cubanite and mackinawite) predominates in the axial carbonate-bearing phoscorite and carbonatite, where it crystallizes around grains of pyrrhotite (with inclusions of pentlandite-cobaltpentlandite and pyrite), and both of these minerals contain exsolution inclusions of sphalerite. In natural sequence of the Kovdor rocks, iron content in pyrrhotite gradually increases from $\mathrm{Fe}_{7} \mathrm{~S}_{8}$ (pyrrhotite-4C, Imm2) to $\mathrm{Fe}_{9} \mathrm{~S}_{10}$ (pyrrhotite-5C, C2 and $P 2_{1}$ ) and $\mathrm{Fe}_{11} \mathrm{~S}_{12}$ (pyrrhotite-6C) due to gradual decrease of crystallization temperature and oxygen fugacity. Low-temperature pyrrhotite $2 \mathrm{C}$ (troilite) occurs as lens-like exsolition inclusions in grains of pyrrhotite-4C (in marginal phoscorite) and pyrrhotite-5C (in axial phoscorite-related carbonatite). Within the phoscorite-carbonatite complex, Co content in pyrrhotite gradually increases from host silicate rocks and marginal forsterite-dominant phoscorite to axial carbonate-rich phoscorite and carbonatite at the expense of $\mathrm{Ni}$ and Fe. Probably, this dependence reflects a gradually decreasing temperature of the primary monosulfide solid solutions crystallization from the pipe margin toward its axis. The Kovdor and Loolekop phoscorite-carbonatite pipes in the Palabora massif have similar sequences of sulfide formation, and the copper specialization of the Palabora massif can be caused by higher water content in its initial melt allowing it to dissolve much larger amounts of sulfur and, correspondingly, chalcophile metals.
\end{abstract}

Keywords: pyrrhotite; chalcopyrite; pentlandite; cobaltpentlandite; typochemistry; crystal structure; Kovdor phoscorite-carbonatite complex 


\section{Introduction}

Sulfur, alongside $\mathrm{H}_{2} \mathrm{O}, \mathrm{CO}_{2}$ and halogens, is an important volatile constituent in magmas [1-3]. Unlike all other major volatile elements, sulfur changes its oxidation state depending on the oxygen fugacity $\left(\mathrm{fO}_{2}\right)$ regime. The two most abundant forms of $\mathrm{S}$ in silicate melts are sulfide $\left(\mathrm{S}^{2-}\right)$ and sulfate $\left(\mathrm{S}^{6+}\right)$ [4-6]. The transition between these two oxidation states is very sharp and occurs over the range of oxygen fugacity between the FMQ equilibrium and $2 \log f \mathrm{O}_{2}$ units above (FMQ + 2). However, sulfur shows radically different behavior in these two oxidation states, and, consequently, the existing sulfur species may provide important insights into the evolution of magmas and mineralizing fluids.

Reduced sulfur actively reacts with iron forming FeS(melt) species; therefore, iron content determines "sulfide capacity" of silicate melts $[4,7,8]$. Besides, iron influences the sulfur oxidation state in silicate melts at given redox conditions $[4,5]$. Various sulfur-bearing species $\left(\mathrm{H}_{2} \mathrm{~S}_{1} \mathrm{SO}_{2}\right.$, $\mathrm{HS}^{-}, \mathrm{S}_{n}{ }^{-}, \mathrm{S}_{n} \mathrm{~S}^{2-}, \mathrm{HSO}_{3}{ }^{-}, \mathrm{HSO}_{4}{ }^{-}, \mathrm{S}_{2} \mathrm{O}_{3}{ }^{2-}, \mathrm{SO}_{3}{ }^{2-}, \mathrm{SO}_{4}{ }^{2-}$ ) serve as ligands for transportation of chalcophile and highly siderophile elements $(\mathrm{Cu}, \mathrm{Ni}, \mathrm{Co}, \mathrm{Zn}, \mathrm{Mo}, \mathrm{Ag}$, $\mathrm{Au}$ and PGE) in silicate melts and magmatic volatiles $[9,10]$, and also control precipitation of the ore-forming elements in magmatic-hydrothermal environment.

Sulfide mineralization is a typical component of the (phoscorite)-carbonatite complexes in alkaline-ultrabasic massifs. The Loolekop phoscorite-carbonatite pipe in the Palabora (Phalaborwa) massif, South Africa (RSA) is a typical example of such complexes, where sulfide mineralization reached the economic level. Sulfides are abundant in alkaline-ultrabasic massifs of the Kola Alkaline Province (NW Russia), and the Kovdor massif is one of the richest. Like the Palabora massif, the Kovdor massif predominantly concentrates sulfides within the Kovdor phoscorite-carbonatite complex, while host silicate rocks (peridotite and foidolite) contain much less sulfides [11,12]. Different aspects of sulfide mineralization in the Kovdor phoscorite-carbonatite complex were discussed in [11-17]. However, almost all of these works presented results of the studies implemented on few random samples with comparatively rare sulfides, while rock-forming sulfides remained almost unstudied.

The general geology of the Kovdor alkaline-ultrabasic massif and its phoscorite-carbonatitre complex has been described by $[11,13,18-21]$, and there is a short geological digest of these works in the first article of this series [22]. In recent years, we have obtained new 3D data on petrography [23-25], composition and properties of economic [22,26-29] and rare minerals [30-36] of the Kovdor phoscorite-carbonatite complex and host ultrabasic and alkaline rocks. This data enabled us to establish formation sequences of the Kovdor massif and its phoscorite-carbonatite complex [21]: peridotite $\rightarrow$ foidolite and melilitolite $\rightarrow$ metasomatic rocks (fenite, diopsidite, phlogopitite, scarn-like rocks) $\rightarrow$ phoscorite and phoscorite-related carbonatite $\rightarrow$ vein calcite carbonatite $\rightarrow$ vein dolomite carbonatite and dolomite-magnetite-serpentine rock. The 3D data on distribution of content, grain size and composition of sulfides presented here will help us to understand the behavior of both sulfur and sulfur-related metals during crystallization and subsolidus evolution of the Kovdor massif.

\section{Materials and Methods}

About 550 core samples of phoscorite, carbonatites and host rocks were taken from 108 boreholes drilled within the Kovdor phoscorite-carbonatite complex. We analyzed thin polished sections of these core samples with a petrographic microscope to estimate textural characteristics, mineral relations and grain size of sulfides. Quantitative relations between magnetic and non-magnetic pyrrhotites were determined in polished sections with a nematic liquid crystal MBBA [37]. Sulfide grain sizes were estimated with the Image Tool 3.0 program [38] as a mean equivalent circular diameter.

Electron-microscope analyses were carried out using a LEO-1450 scanning electron microscope with a Röntek energy-dispersive spectrometer. Chemical compositions of sulfides were determined with the Cameca MS-46 electron microprobe (Geological Institute of the Kola Science Center, Russian Academy of Sciences) operating in a wavelength-dispersive mode at $20 \mathrm{kV}$ and 20-30 nA. The electron beam diameter used was $1-10 \mu \mathrm{m}$. The applied standards and detection limits are listed in Table 1. Abbreviations used include Acn (acanthite), Ap (hydroxylapatite), Apn (argentopentlandite), 
Bdy (baddeleyite), Bn (bornite), Brt (barite), Cal (calcite), Cbn (cubanite), Ccp (chalcopyrite), Clc (clinochlore), Cls (clausthalite), Djf (djerfisherite), Dol (dolomite), Fo (forsterite), Ght (goethite), Gn (galena), Hss (hessite), Hwl (hawleyite), Mag (magnetite), Mch (moncheite), Mck (mackinawite), Mrc (marcasite), Nph (nepheline), Pcl (pyrochlore), Phl (phlogopite), Pn (pentlandite), Po (pyrrhotite), Py (pyrite), Sgn (siegenite), Sp (sphalerite), Spl (spinel), Srp (serpentine), Tro (troilite), Ttn (titanite), Val (valleriite) and Vlt (violarite).

Bulk-rock samples were analyzed by the Tananaev Institute of Chemistry of KSC RAS (Apatity) by means of inductively coupled plasma-mass spectrometry (ICP-MS) performed with an ELAN 9000 DRC-e mass spectrometer (Perkin Elmer, Waltham, MA, USA). For the analyses, the samples were dissolved in a mixture of concentrated hydrofluoric and nitric acids with distillation of silicon and further addition of hydrogen peroxide to a cooled solution to suppress hydrolysis of polyvalent metals [39].

Cation contents were calculated with the MINAL program of D. Dolivo-Dobrovolsky [40]. Statistical analyses were carried out with the STATISTICA 8.0 [41] and TableCurve 2.0 [42] programs. For the statistics, resulting values of the analyses below the detection limit (see Table 1) were considered to be 10 times lower than the limit. Geostatistical studies and 3D modelling were conducted with the MICROMINE 16 program [43]. Interpolation was performed with ordinary kriging. Automatic 3D geological mapping (Figure 1a) was performed by means of conversion of the rocks chemical composition to mineral composition by logical computation [24].

Table 1. Parameters of EPMA analyses.

\begin{tabular}{|c|c|c|c|c|c|}
\hline Element & $\begin{array}{c}\text { Detection } \\
\text { Limit, wt \% }\end{array}$ & $\begin{array}{l}\text { Standards for } \\
\text { EPMA Analyses }\end{array}$ & Element & $\begin{array}{c}\text { Detection } \\
\text { Limit, wt \% }\end{array}$ & $\begin{array}{c}\text { Standards for EPMA } \\
\text { Analyses }\end{array}$ \\
\hline $\mathrm{Mg}$ & 0.1 & Pyrope & Se & 0.08 & Synthetic PbSe \\
\hline $\mathrm{Al}$ & 0.05 & Pyrope & Mo & 0.1 & Metallic molybdenum \\
\hline $\mathrm{Si}$ & 0.05 & Diopside & $\mathrm{Pd}$ & 0.05 & Metallic palladium \\
\hline $\mathrm{S}$ & 0.05 & Synthetic $\mathrm{Fe}_{10} \mathrm{~S}_{11}$ & $\mathrm{Ag}$ & 0.05 & Metallic silver \\
\hline $\mathrm{K}$ & 0.03 & Wadeite & $\mathrm{Cd}$ & 0.05 & Synthetic CdS \\
\hline $\mathrm{Ca}$ & 0.03 & Diopside & Sn & 0.05 & Metallic tin \\
\hline $\mathrm{Mn}$ & 0.01 & Synthetic $\mathrm{MnCO}_{3}$ & $\mathrm{Sb}$ & 0.05 & Antimony \\
\hline $\mathrm{Fe}$ & 0.01 & Synthetic $\mathrm{Fe}_{10} \mathrm{~S}_{11}$ & $\mathrm{Te}$ & 0.05 & Synthetic PbTe \\
\hline $\mathrm{Co}$ & $0.01-0.03$ & Metallic cobalt & $\mathrm{Pt}$ & 0.05 & Metallic platinum \\
\hline $\mathrm{Ni}$ & 0.01 & Synthetic NiAs & $\mathrm{Au}$ & 0.05 & Metallic gold \\
\hline $\mathrm{Cu}$ & 0.01 & Metallic copper & $\mathrm{Pb}$ & 0.05 & Synthetic PbSe \\
\hline $\mathrm{Zn}$ & 0.01 & Synthetic ZnO & $\mathrm{Bi}$ & 0.06 & Bismuth \\
\hline As & 0.05 & Synthetic NiAs & & & \\
\hline
\end{tabular}

Crystal structures of pyrrhotite samples (00-01, 36/33, 00-10-41, 01-11-91, 00-51) were studied by means of Agilent Technologies Xcalibur Eos diffractometer operated at $50 \mathrm{kV}$ and $40 \mathrm{~mA}$. More than a hemisphere of three-dimensional data was collected at $100 \mathrm{~K}$ temperature by monochromatic MoK $\alpha$ X-radiation with frame widths of $1^{\circ}$ and $5-15 \mathrm{~s}$ count for each frame. The crystal structures were refined in standard and non-standard settings of different space groups: $P-6 \mathrm{~m} 2, P 312, P 32, P-3 \mathrm{~m}, P-3$, $P 3 \mathrm{~m}, \mathrm{Cmce}, \mathrm{Cca}, \mathrm{Cc}, \mathrm{C} 222_{1}, C 2, P 2_{1}$ for the $5 \mathrm{C}$-polytype and P-6m2,Aem2, Amm2, C2/m, C/m, C2, $F 2 / d$, Imm 2 for the 4C-polytype by means of the SHELX program [44] incorporated in the OLEX2 program package [45]. The final models were chosen according to the following criteria: absence of violating reflections, lower means of $R$-factors and GOOF, absence or low number of atoms with physically unrealistic anisotropic displacement parameters (without restraints). Crystal structures

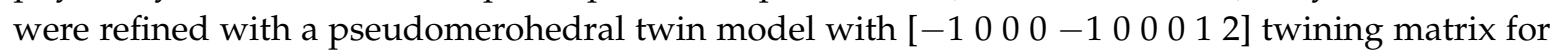
the $C 2$ and $P 2_{1}$ models. Empirical absorption correction was applied in the CrysAlisPro program [46] using spherical harmonics implemented in the SCALE3 ABSPACK scaling algorithm. The crystal structures were visualized with the Diamond 3.2f program [47]. 
a
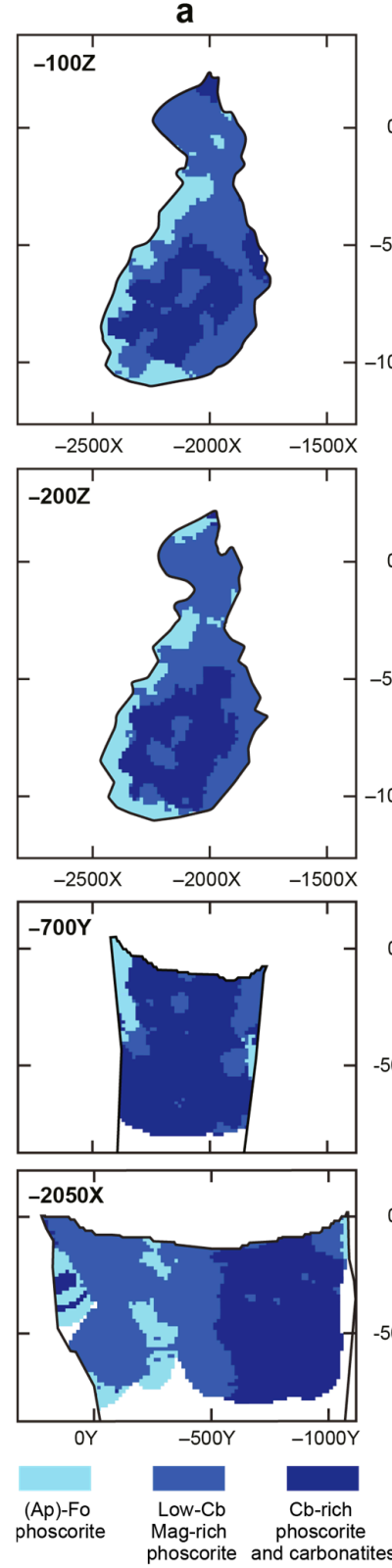

b
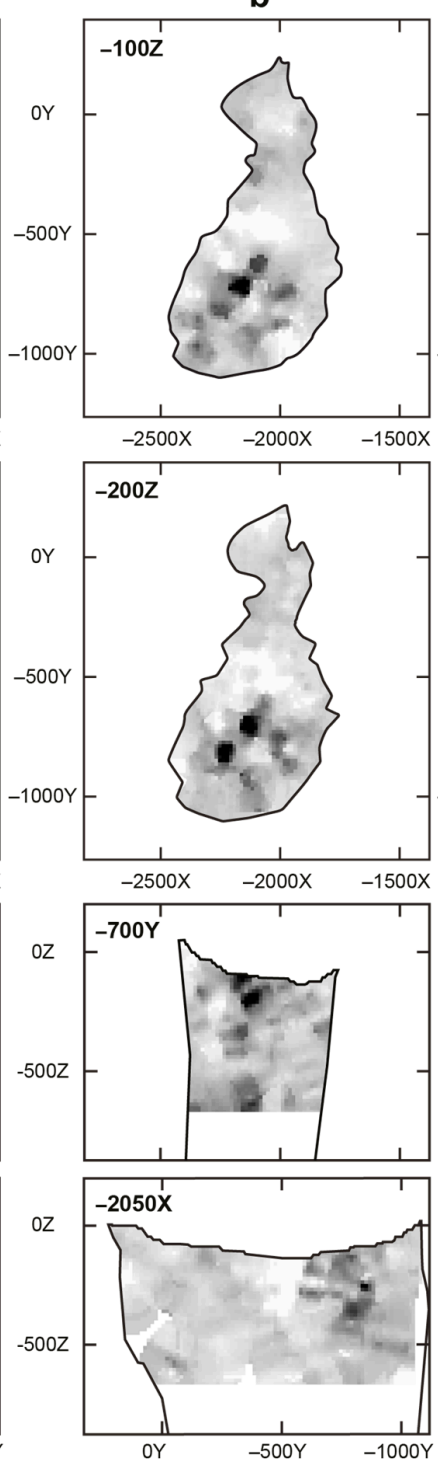

0.1
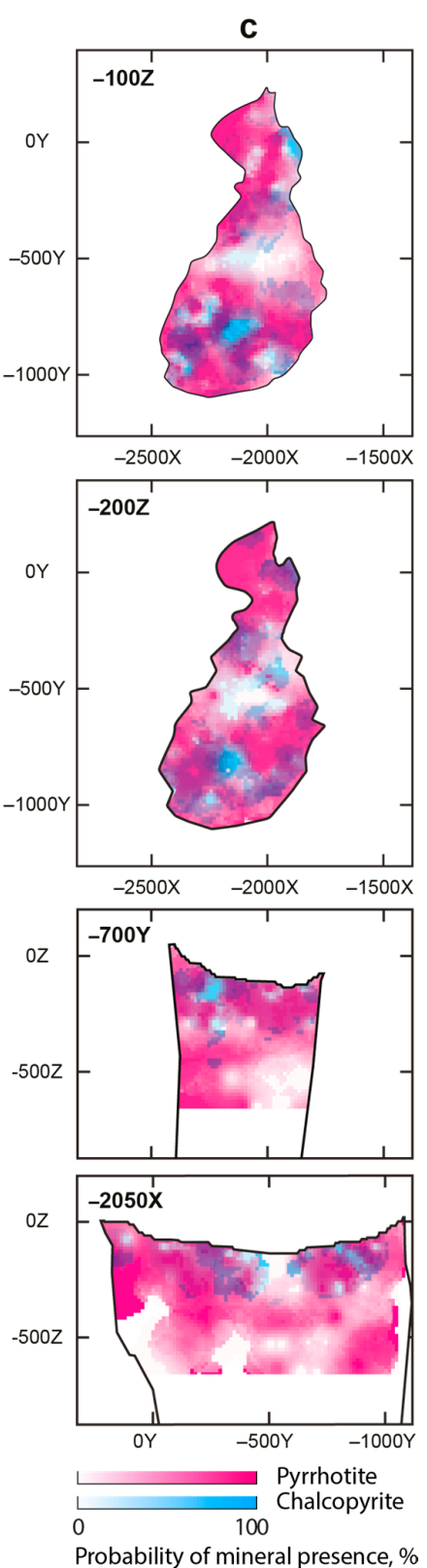

Figure 1. Distribution of rock types (a), sulfur content (b) and probability of pyrrhotite and chalcopyrite presence (c) within the Kovdor phoscorite-carbonatite complex.

\section{Results}

\subsection{Sulfur Mineralization}

In primary silicate rocks of the Kovdor massif, average sulfur content is comparatively low (Table 2), but it becomes higher in apo-peridotite metasomatic diopsidite and phlogopitite. Within the phoscorite-carbonatite pipe, sulfur content increases from marginal low-carbonate phoscorite to axial calcite-rich phoscorite and calcite carbonatite (Figure 1b). Besides sulfur, the Kovdor sulfuric compounds include $\mathrm{Fe}, \mathrm{Co}, \mathrm{Ni}, \mathrm{Cu}, \mathrm{Zn}, \mathrm{Ag}, \mathrm{Pb}$ and $\mathrm{Ba}$ (see Table 1). Many of these metals initially concentrated in rock-forming forsterite $(\mathrm{Ni})$, apatite $(\mathrm{Ba})$, magnetite $(\mathrm{Fe}, \mathrm{Co}, \mathrm{Zn})$ and pyrochlore $(\mathrm{Pb})$, and demonstrate unclear or even negative correlation with sulfur. Nevertheless, sulfuric compounds inherited initial distribution of these metals in earlier minerals resulting in concentric distribution corresponding to the secondary sulfides and sulfates within the phoscorite-carbonatite complex. 
Table 2. Median contents of sulfide-forming elements in rocks of the Kovdor massif.

\begin{tabular}{cccccc}
\hline Rock & $\begin{array}{c}\text { Host Silicate } \\
\text { Rock }\end{array}$ & $\begin{array}{c}\text { (Ap)-Fo } \\
\text { Phoscorite }\end{array}$ & $\begin{array}{c}\text { Low-Cb Mag-Rich } \\
\text { Phoscorite }\end{array}$ & $\begin{array}{c}\text { Cal-Rich Phoscorite and } \\
\text { Related Carbonatite }\end{array}$ & $\begin{array}{c}\text { Vein Calcite } \\
\text { Carbonatite }\end{array}$ \\
\hline$n$ & 44 & 17 & 90 & 50 & 16 \\
$\mathrm{~S}, \mathrm{wt} \%$ & 0.22 & 0.20 & 0.15 & 0.29 & 1.53 \\
$\mathrm{Fe}$ & 6.49 & 7.88 & 29.79 & 17.48 & 3.85 \\
$\mathrm{Cu}, \mathrm{ppm}$ & 56 & 44 & 37 & 78 & 55 \\
$\mathrm{Zn}$ & 89 & 100 & 198 & 717 & 28 \\
$\mathrm{Co}$ & 40 & 65 & 92 & 17 & 17 \\
$\mathrm{Ni}$ & 111 & 49 & 39 & 6 & 1 \\
$\mathrm{Ag}$ & 2 & 1 & 8 & 2 & 3 \\
$\mathrm{~Pb}$ & 1 & 1 & 1 & & \\
\hline
\end{tabular}

In the Kovdor rocks, major concentrators of sulfur are sulfides, mainly, pyrrhotite and chalcopyrite (Figure 1c), while sulfates, mainly, barite, are the products of low-temperature alteration of sulfides. Pyrrhotite is a common accessory to a rock-forming mineral of the most phoscorite and carbonatites varieties, apart from vein dolomite carbonatite and the related dolomite-magnetite-serpentine metasomatic rock. Chalcopyrite is closely associated with pyrrhotite, being predominantly concentrated in carbonate-rich phoscorite, phoscorite-related carbonatite and vein calcite carbonatite of the ore-pipe apical part (up to 20 modal \%). In the apical part of the pipe axial zone, there is calcite-rich phoscorite with rock-forming chalcopyrite (up to 30 modal \%).

All other sulfides and sulfates resulted from subsolidus exsolution and low-temperature hydrothermal alteration of pyrrhotite and chalcopyrite. Pyrrhotite contains exsolution inclusions of pentlandite-cobaltpentlandite (almost always) and troilite (rarely), and chalcopyrite carries exsolution inclusions of sphalerite (common) and cubanite (rare). Pyrite and valleriite are spread products of pyrrhotite and chalcopyrite alteration, while primary bornite sometimes occurs as relicts within secondary chalcopyrite. Rare secondary sulfides include djerfisherite, marcasite (after both pyrrhotite and chalcopyrite), chalcocite and covellite (after chalcopyrite only). In addition, galena, violarite, mackinawite, moncheite, petzite, hessite and clausthalite form separate inclusions in pyrrhotite, while acanthite, argentopentlandite, altaite, galena, hawleyite, siegenite, tsumoite, volynskite, wittichenite occur as inclusions in bornite and chalcopyrite.

\subsection{Pyrrhotite and Products of Its Alteration}

In the Kovdor massif, pyrrhotite- $4 \mathrm{C}, \mathrm{Fe}_{7} \mathrm{~S}_{8}$, pyrrhotite- $5 \mathrm{C}, \mathrm{Fe}_{9} \mathrm{~S}_{10}$, and pyrrhotite-2C (troilite), $\mathrm{FeS}$ were found and structurally verified, while presence of pyrrhotite-6C, $\mathrm{Fe}_{10} \mathrm{~S}_{11}$ was established only according to its composition. Few pyrrhotite modifications often occur within one sample, and even within one grain of pyrrhotite (Figure 2a); however, non-magnetic monoclinic modification $5 \mathrm{C}$ always predominates (in average, $88 \mathrm{vol} . \%$ ). Content of ferrimagnetic orthorhombic pyrrhotite- $4 \mathrm{C}$ reaches $50 \mathrm{vol} . \%$ in host silicate rocks and marginal (apatite)-forsterite phoscorite, $30 \mathrm{vol}$ \% in intermediate low-carbonate magnetite-rich phoscorite, 20 vol. \% in axial calcite-rich phoscorite and related carbonatite, and 15 vol. \% in vein calcite and dolomite carbonatite [14]. Pyrrhotite-6C is the latest modification that substitutes magnetite and chalcopyrite (mainly, in calcite carbonatite), and forms pyrrhotite-pyrite intergrowth resulting from exsolution of earlier pyrrhotite-5C or $-4 C$. Pyrrhotite- $4 \mathrm{C}$ forms separate grains, marginal zones of non-magnetic pyrrhotite crystals and thin (up to $50 \mu \mathrm{m}$ ) lens-like inclusions in pyrrhotite-5C (see Figure 2a). Exsolution hexagonal pyrrhotite-2C (troilite) is found in about $5 \%$ of the samples (mainly, in marginal apatite-forsterite phoscorite and axial phoscorite-related carbonatite) as lens-like inclusions in grains of pyrrhotite-4C and pyrrhotite-5C (Figure $2 b$ ).

In peridotite, rounded or irregularly shaped pyrrhotite grains (up to $120 \mu \mathrm{m}$ in diameter) with exsolution inclusions of pentlandite fill interstices between rock-forming olivine and diopside. In foidolite, there are sporadic pyrrhotite grains in cancrinitized nepheline grains (Figure 2c) and late calcite veinlets. Apo-peridotite metasomatites, especially carbonatized and apatitized, contain 
up to 3 modal \% of pyrrhotite that fills interstices between grains of rock-forming minerals in close association with chalcopyrite, magnetite and ilmenite (Figure $2 \mathrm{~d}$ ).
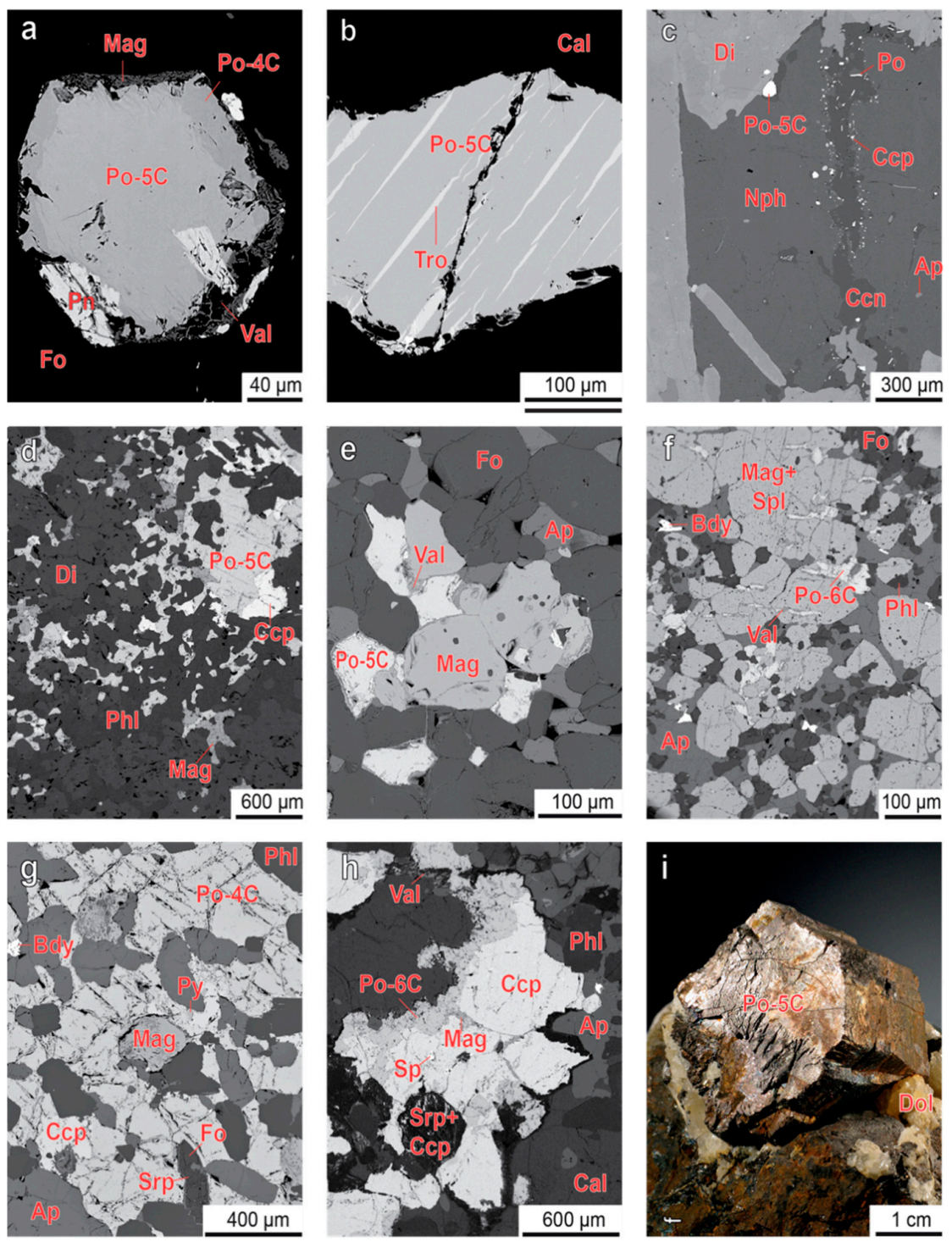

Figure 2. Typical pyrrhotite morphology in rocks of the Kovdor massif: (a) pseudohexagonal crystal of pyrrhotite-5C with inclusions of pentlandite replaced with pyrrhotite-4C (F-phoscorite 927/87.4); (b) exsolution inclusions of troilite in pyrrhotite-5C (a, phoscorite-related carbonatite 924/26.7); (c) plate crystals of pyrrhotite-5C in cancrinitized nepheline (foidolite 949/209.2); (d) irregularly shaped intergrowths of pyrrhotite-5C, magnetite and chalcopyrite (diopside-phlogopite rock 1010/619.4); (e) intergrowth of pyrrhotite-5C with magnetite (AF-phoscorite 956/70.7); (f) interstitial aggregates and veinlets of pyrrhotite-6C in magnetite (MAF-phoscorite 905/160.0); (g) aggregates of pyrrhotite-4C in a sulfide segregation (CMAF-phoscorite 1004/656.5); (h) granular rims of pyrrhotite-6C around chalcopyrite grains (phoscorite-related carbonatite 975/270.0); (i) well-shaped crystal of pyrrhotite-5C (vein dolomite carbonatite K-2011-5). BSE-images (a-h) and macrophoto (i). Mineral abbreviations see in the Section 2.

As mentioned above, pyrrhotite is a predominant accessory to rock-forming sulfide of phoscorite and carbonatite. In marginal forsteritite and apatite-forsterite phoscorite, pyrrhotite (up to 0.2 modal \%) occurs within and between forsterite grains as pseudohexagonal plate crystals (up to $500 \mu \mathrm{m}$ in diameter) with exsolution lamellae of pentlandite inside (see Figure 2a), as well as irregularly shaped 
grains in close intergrowth with magnetite (Figure 2e). Content of pyrrhotite in phoscorite increases with growth of magnetite amount and reaches 8 modal \% in intermediate low-carbonate magnetite-rich phoscorite. Herein, pyrrhotite usually forms close intergrowths with magnetite, and, together with valleriite, replaces earlier magnetite and fills fractures in its grains (Figure 2f). Such secondary pyrrhotite often inherits cubic inclusions of spinel from exsolved Mg-Al-rich magnetite.

Gradual transition of low-carbonate magnetite-rich phoscorite into axial calcite-rich phoscorite and phoscorite-related carbonatite is accompanied by growth of pyrrhotite content and disappearance of its connection with magnetite. In this type of rock, there are sulfide-rich areas (up to $8 \mathrm{~m}$ in diameter), where pyrrhotite (up to 50 modal \%) and chalcopyrite cement separate grains of all other minerals (Figure 2g). Besides, pyrrhotite forms here porous rims around chalcopyrite grains (Figure 2h) and tabular to short prismatic crystals (up to $2 \mathrm{~cm}$ in diameter) with hexagonal prismatic $\{10-10\}$ and pinacoidal $\{0001\}$ faces. In selvages of vein calcite and dolomite carbonatites, pyrrhotite occurs as bronze-yellow platy crystals (up to $15 \mathrm{~cm}$ in diameter and $1.5 \mathrm{~cm}$ thick), partially replaced with pyrite and goethite (Figure 2i).

Mean equivalent circular diameter of pyrrhotite grains (Table 3) increases insignificantly from $80 \mu \mathrm{m}$ in marginal (apatite)-forsterite phoscorite to $160 \mu \mathrm{m}$ in intermediate low-carbonate magnetite-rich phoscorite, and then to $200 \mu \mathrm{m}$ in axial calcite-rich phoscorite and carbonatite. This trend is similar to that of co-existing rock-forming and accessory minerals [21,26,27].

Table 3. Grain size and chemical composition of the pyrrhotite group minerals (mean $\pm \mathrm{SD} / \mathrm{min}-\mathrm{max}$ ).

\begin{tabular}{|c|c|c|c|c|c|c|c|}
\hline \multirow[b]{2}{*}{ Rock } & \multicolumn{2}{|c|}{ Host Rock } & \multicolumn{3}{|c|}{ Phoscorite and Related Carbonatite } & \multicolumn{2}{|c|}{ Vein Carbonatite } \\
\hline & Foidolite & Diopsidite & (Ap)-Fo & $\begin{array}{l}\text { Low-Cb } \\
\text { Mag-rich }\end{array}$ & Cal-rich & Cal & Dol \\
\hline$n$ & 9 & 27 & 13 & 60 & 94 & 26 & 25 \\
\hline$D, \mu \mathrm{m}$ & $\begin{array}{c}100 \pm 80 \\
15-300\end{array}$ & $\begin{array}{c}140 \pm 90 \\
10-300\end{array}$ & $\begin{array}{c}120 \pm 90 \\
50-400\end{array}$ & $\begin{array}{c}200 \pm 80 \\
50-450\end{array}$ & $\begin{array}{c}220 \pm 90 \\
10-600\end{array}$ & $\begin{array}{c}230 \pm 90 \\
100-600\end{array}$ & $\begin{array}{c}200 \pm 100 \\
50-600\end{array}$ \\
\hline $\mathrm{S}, \mathrm{wt} \%$ & $\begin{array}{c}39.2 \pm 0.5 \\
38.54-40.38\end{array}$ & $\begin{array}{c}39.1 \pm 0.5 \\
37.67-39.98\end{array}$ & $\begin{array}{c}39 \pm 1 \\
36.72-39.82\end{array}$ & $\begin{array}{c}39.1 \pm 0.6 \\
36.31-40.52\end{array}$ & $\begin{array}{c}38.9 \pm 0.7 \\
35.81-40.36\end{array}$ & $\begin{array}{c}39.0 \pm 0.4 \\
38.27-39.77\end{array}$ & $\begin{array}{c}39.0 \pm 0.5 \\
37.74-39.77\end{array}$ \\
\hline $\mathrm{Fe}$ & $\begin{array}{c}60.5 \pm 0.5 \\
59.83-61.11\end{array}$ & $\begin{array}{c}60.6 \pm 0.9 \\
59.31-63.01\end{array}$ & $\begin{array}{c}61 \pm 2 \\
59.77-64.13\end{array}$ & $\begin{array}{c}60.8 \pm 0.8 \\
58.18-63.51\end{array}$ & $\begin{array}{c}60.9 \pm 0.8 \\
58.93-63.37\end{array}$ & $\begin{array}{c}60.8 \pm 0.5 \\
59.77-61.87\end{array}$ & $\begin{array}{c}60.7 \pm 0.6 \\
59.37-61.92\end{array}$ \\
\hline Co & $\begin{array}{c}0.1 \pm 0.1 \\
<0.01-0.43\end{array}$ & $\begin{array}{l}0.06 \pm 0.06 \\
<0.01-0.19\end{array}$ & $\begin{array}{c}0.1 \pm 0.1 \\
<0.01-0.39\end{array}$ & $\begin{array}{c}0.2 \pm 0.1 \\
<0.01-0.39\end{array}$ & $\begin{array}{c}0.2 \pm 0.1 \\
<0.01-0.54\end{array}$ & $\begin{array}{c}0.14 \pm 0.09 \\
0.02-0.36\end{array}$ & $\begin{array}{l}0.13 \pm 0.08 \\
<0.01-0.33\end{array}$ \\
\hline $\mathrm{Ni}$ & $\begin{array}{l}0.3 \pm 0.1 \\
0.03-0.44\end{array}$ & $\begin{array}{c}0.3 \pm 0.2 \\
<0.01-0.82\end{array}$ & $\begin{array}{c}0.2 \pm 0.1 \\
<0.01-0.38\end{array}$ & $\begin{array}{l}0.06 \pm 0.09 \\
<0.01-0.36\end{array}$ & $\begin{array}{l}0.04 \pm 0.09 \\
<0.01-0.77\end{array}$ & $\begin{array}{l}0.01 \pm 0.02 \\
<0.01-0.08\end{array}$ & $\begin{array}{c}0.1 \pm 0.1 \\
<0.01-0.38\end{array}$ \\
\hline $\mathrm{Fe}$, at. $\%$ & $\begin{array}{c}46.8 \pm 0.4 \\
45.85-47.35\end{array}$ & $\begin{array}{c}47.0 \pm 0.7 \\
46.02-48.98\end{array}$ & $\begin{array}{c}48 \pm 1 \\
46.34-50.02\end{array}$ & $\begin{array}{c}47.1 \pm 0.7 \\
45.26-50.10\end{array}$ & $\begin{array}{c}47.2 \pm 0.8 \\
45.80-50.22\end{array}$ & $\begin{array}{c}47.2 \pm 0.4 \\
46.20-47.87\end{array}$ & $\begin{array}{c}47.2 \pm 0.5 \\
46.21-48.08\end{array}$ \\
\hline $\mathrm{Ni}$ & $\begin{array}{l}0.2 \pm 0.1 \\
0.00-0.32\end{array}$ & $\begin{array}{l}0.2 \pm 0.2 \\
0.00-0.59\end{array}$ & $\begin{array}{l}0.1 \pm 0.1 \\
0.00-0.26\end{array}$ & $\begin{array}{c}0.04 \pm 0.07 \\
0.00-0.26\end{array}$ & $\begin{array}{c}0.03 \pm 0.07 \\
0.00-0.58\end{array}$ & $\begin{array}{c}0.00 \pm 0.01 \\
0.00-0.05\end{array}$ & $\begin{array}{c}0.06 \pm 0.08 \\
0.00-0.31\end{array}$ \\
\hline Co & $\begin{array}{l}0.1 \pm 0.1 \\
0.00-0.32\end{array}$ & $\begin{array}{c}0.04 \pm 0.05 \\
0.00-0.16\end{array}$ & $\begin{array}{c}0.05 \pm 0.07 \\
0.00-0.27\end{array}$ & $\begin{array}{c}0.11 \pm 0.08 \\
0.00-0.27\end{array}$ & $\begin{array}{c}0.14 \pm 0.09 \\
0.00-0.38\end{array}$ & $\begin{array}{c}0.10 \pm 0.06 \\
0.00-0.27\end{array}$ & $\begin{array}{c}0.10 \pm 0.07 \\
0.00-0.27\end{array}$ \\
\hline S & $\begin{array}{c}52.9 \pm 0.4 \\
52.55-53.88\end{array}$ & $\begin{array}{c}52.8 \pm 0.6 \\
51.02-53.56\end{array}$ & $\begin{array}{c}52 \pm 1 \\
49.98-53.39\end{array}$ & $\begin{array}{c}52.7 \pm 0.7 \\
49.90-54.47\end{array}$ & $\begin{array}{c}52.6 \pm 0.7 \\
49.73-53.82\end{array}$ & $\begin{array}{c}52.7 \pm 0.4 \\
52.03-53.53\end{array}$ & $\begin{array}{c}52.7 \pm 0.5 \\
51.76-53.36\end{array}$ \\
\hline
\end{tabular}

Chemical composition of pyrrhotite (Table 3, Figure 3a) varies from $\mathrm{Me}_{7} \mathrm{~S}_{8}$ (pyrrhotite-4C) to $\mathrm{MeS}$ (pyrrhotite-2C), with intensive maximum at $\mathrm{Me}_{9} \mathrm{~S}_{10}$ (pyrrhotite-5C). Approximation of total metal content histogram by the corresponding Gaussians with fixed positions at Me $=46.66$ for $\mathrm{Fe}_{7} \mathrm{~S}_{8}, 47.36$ for $\mathrm{Fe}_{9} \mathrm{~S}_{10}, 47.82$ for $\mathrm{Fe}_{11} \mathrm{~S}_{12}$ and 50.00 for $\mathrm{FeS}$ has confirmed a sharp predominance of pyrrhotite-5C with subordinate roles of 6C, $4 \mathrm{C}$ and, especially, 2C modifications. Contents of iron and sulfur are distributed in accordance with normal law (Figure 3b), while cobalt and nickel are characterized by lognormal and exponential distributions correspondingly (Figure 3c,d).

Iron content in pyrrhotite (exclusive of exsolution troilite) gradually increases from earlier host silicate rocks to the latest vein carbonatites (Figure 4a), which is fully in accordance with 
gradual increase of pyrrhotite- $5 \mathrm{C}$ fraction due to presence of pyrrhotite- $4 \mathrm{C}$ in this sequence. Taking into account pyrrhotite structural data according to [48], where $\mathrm{Fe}_{7} \mathrm{~S}_{8}=\mathrm{Fe}^{2+}{ }_{5} \mathrm{Fe}^{3+}{ }_{2} \square \mathrm{S}^{2-}{ }_{8}$, $\mathrm{Fe}_{9} \mathrm{~S}_{10}=\mathrm{Fe}^{2+}{ }_{7} \mathrm{Fe}^{3+}{ }_{2} \square \mathrm{S}^{2-}{ }_{10}$ and $\mathrm{Fe}_{11} \mathrm{~S}_{12}=\mathrm{Fe}^{2+}{ }_{9} \mathrm{Fe}^{3+}{ }_{2} \square \mathrm{S}^{2-}{ }_{12}$, one can see a gradual decrease of $\mathrm{Fe}^{3+} / \mathrm{Me}^{2+}$ ratio in natural rock sequence of the Kovdor massif (Figure 4b), and from marginal (apatite)-forsterite phoscorite with pyrrhotite-4C to intermediate low-carbonate magnetite-rich phoscorite with pyrrhotite- $5 \mathrm{C}$ and, finally, calcite-rich phoscorite and calcite carbonaite with pyrrhotite-5C and $-6 \mathrm{C}$ (Figure $5 \mathrm{a}$ ).

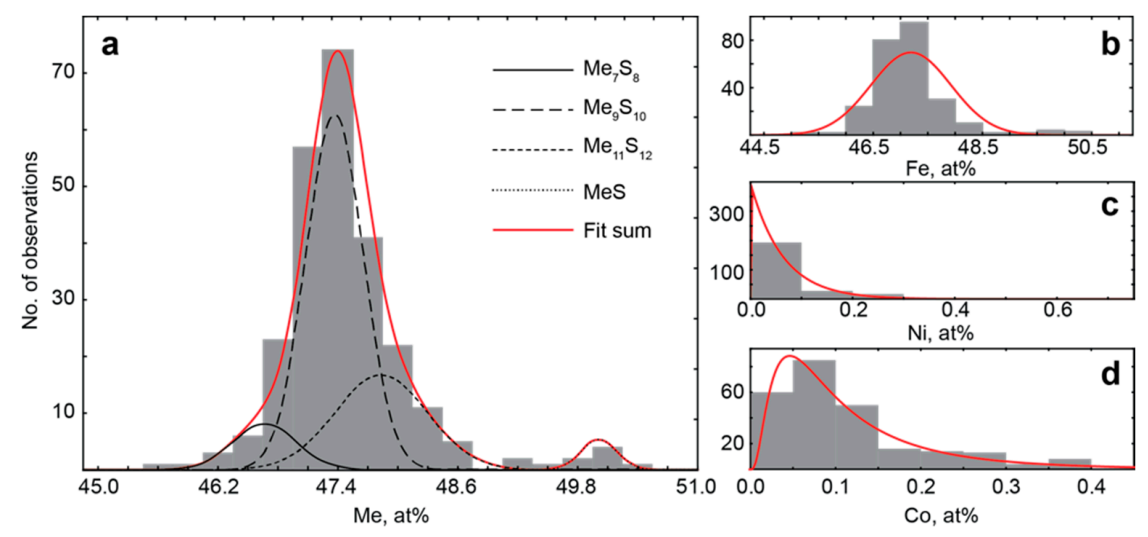

Figure 3. Frequency histograms of the total metals (a), Fe (b), Ni (c) and Co (d) contents in pyrrhotite and troilite of the Kovdor phoscorite-carbonatite complex.
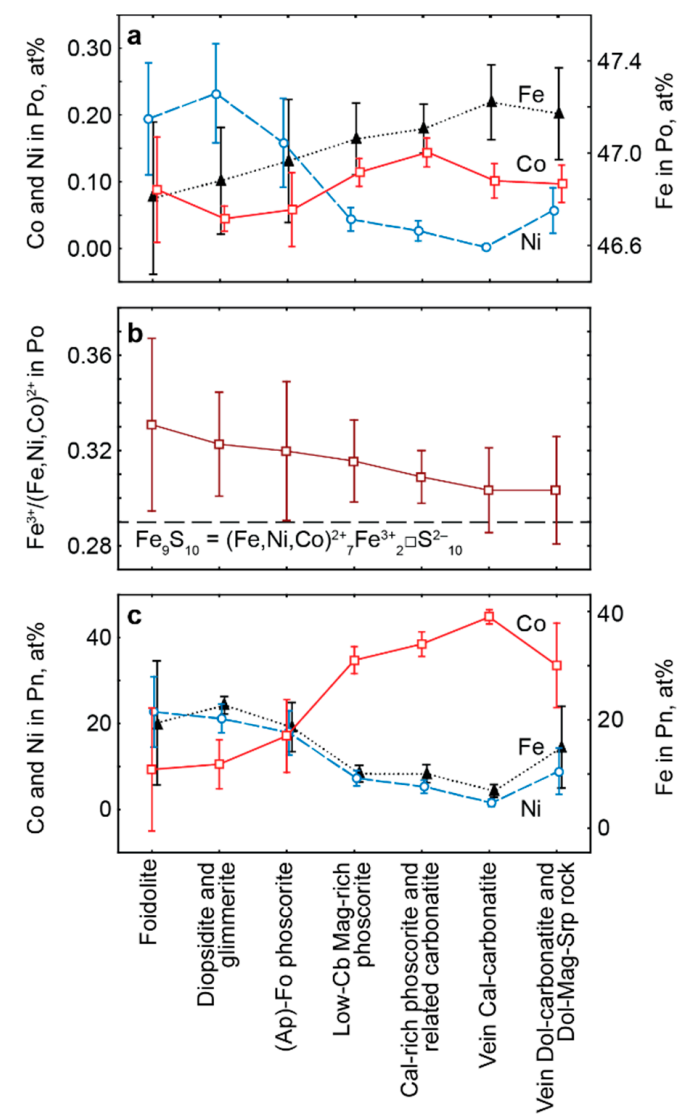

Figure 4. Mean contents of $\mathrm{Fe}, \mathrm{Ni}$ and $\mathrm{Co}$ (at. \%, mean $\pm 95 \%$ confidence interval) in pyrrhotite ((a) without the troilite account) and exsolution pentlandite-cobaltpentlandite (c), as well as ratio $\mathrm{Fe}^{3+} / \mathrm{Me}^{2+}$ in pyrrhotite (b), in the order of the rock formation sequence. 

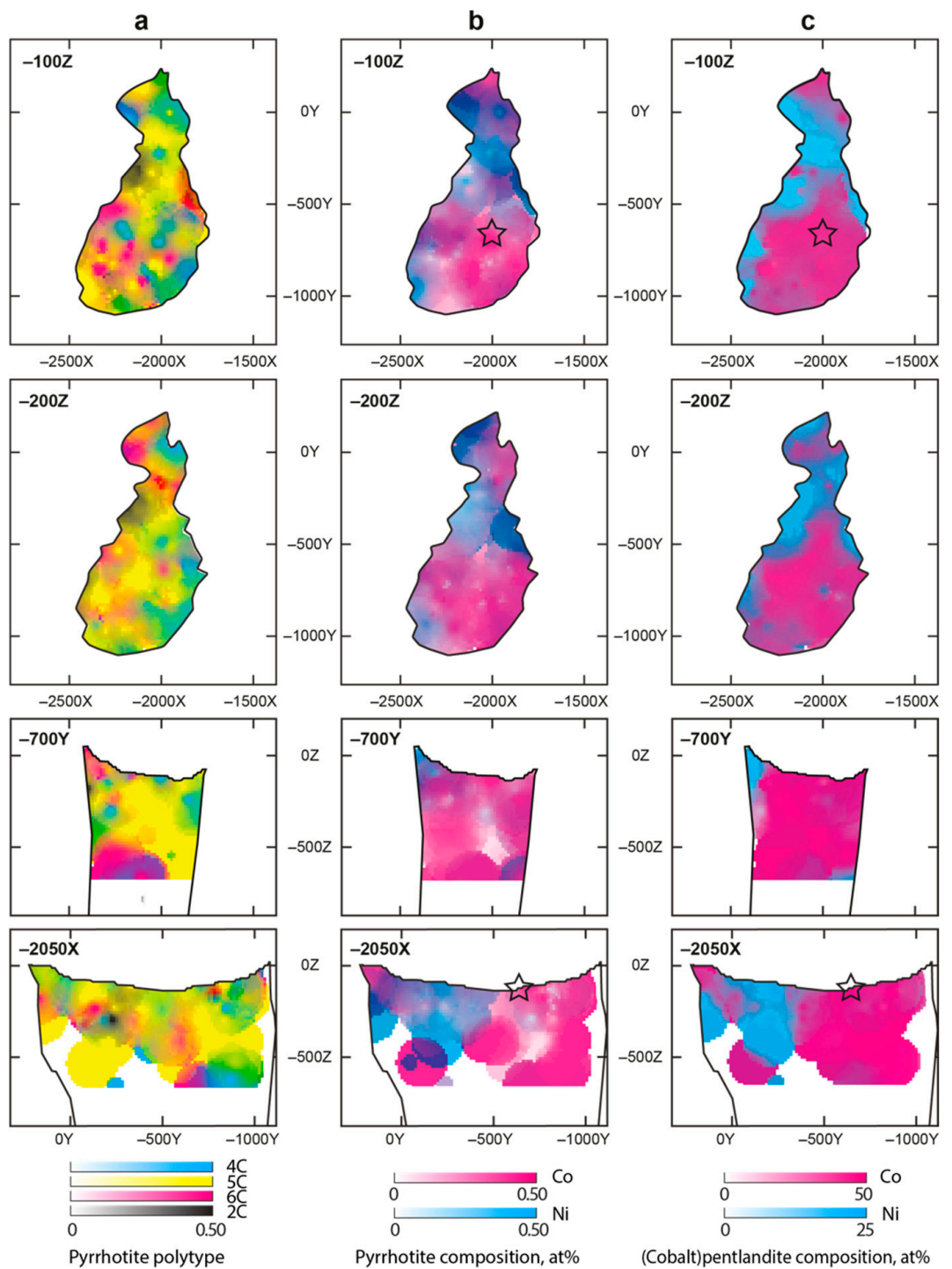

Figure 5. Distribution of pyrrhotite polytypes (a), content of Ni and Co in pyrrhotite (b) and pentlandite-cobaltpentlandite (c) within the phoscorite-carbonatite complex (black contour). Stars denote TL of pakhomovskyite, $\mathrm{Co}_{3}\left[\mathrm{PO}_{4}\right]_{2} \cdot 8 \mathrm{H}_{2} \mathrm{O}$.

Experimental details and crystallographic parameters of structurally different pyrrhotites are given in Table 4. The site occupancy factors (s.o.f.) were refined using the scattering curves for neutral atoms given in the International Tables for Crystallography [49]. Due to the large scope of structural information (atom coordinates, bond-lengths, displacement parameters for samples 1-5), these data can be obtained from the CIFs, which are available as Supplementary Materials.

The pyrrhotite crystal structure was firstly described by Nils Alsen [50] in the space group $P 6_{3} / m m c$ with unit cell parameters $a=3.43, c=5.68 \AA$. The description was based upon hexagonal-close packing stacked perpendicular to the $c$ axis, where sulfur atoms approximately occupy the nodes, and iron atoms are regularly arranged in octahedral interstices of sulfur atoms [51]. The vacancies between iron sites are in ordered arrangement, and confined to alternate layers of iron atoms and normal to the $c$ axis [52,53]. Formation of different pyrrhotite polytypes is caused by ordered arrangement of vacancies and/or $\mathrm{Fe}^{2+} / \mathrm{Fe}^{3+}$ atoms that results in formation of superstructures [53]. Random arrangement of vacancies leads to the formation of hexagonal 1C polytype, their partial ordering causes orthorhombic $4 \mathrm{C}$ modification, and fully ordered vacancy distribution produces monoclinic 5C, 6C and modulated NC structures. Up today, 4C, 5C, 6C pyrrhotite polytypes and 
modulated $N C$ structures with $N=4.88,5.5$ etc. were reported [52,54,55]. The $N$ is defined as a number of supercell reflections along $c^{*}$ direction (Figure 6) situating between bright reflections of a hexagonal cell.

Table 4. Structural data for studied pyrrhotites.

\begin{tabular}{|c|c|c|c|c|c|}
\hline Sample & $1(00-01)$ & $2(36-33)$ & $3(00-10-41)$ & 4 (01-11-91) & $5(00-51)$ \\
\hline Modification & $4 \mathrm{C}$ & $5 \mathrm{C}$ & $5 \mathrm{C}$ & $5 \mathrm{C}$ & $5 \mathrm{C}$ \\
\hline Refined formula & $\mathrm{Fe}_{6.78} \mathrm{~S}_{8}$ & $\mathrm{Fe}_{8.91} \mathrm{Ni}_{0.25} \mathrm{~S}_{10}$ & $\mathrm{Fe}_{8.99} \mathrm{~S}_{10}$ & $\mathrm{Fe}_{8.84} \mathrm{~S}_{10}$ & $\mathrm{Fe}_{8.88} \mathrm{~S}_{10}$ \\
\hline Formula weight & 634.86 & 833.04 & 822.41 & 814.45 & 816.41 \\
\hline Crystal system & orthorhombic & monoclinic & monoclinic & monoclinic & monoclinic \\
\hline Space group & $\operatorname{Im} m 2$ & C2 & C2 & C2 & $P 2_{1}$ \\
\hline$a(\AA)$ & $22.678(4)$ & $11.8624(9)$ & $11.8875(11)$ & $11.8706(7)$ & $6.8477(5)$ \\
\hline$\alpha\left({ }^{\circ}\right)$ & 90 & 90 & 90 & 90 & 90 \\
\hline$\beta\left({ }^{\circ}\right)$ & 90 & $89.897(8)$ & $90.023(8)$ & $89.982(5)$ & $119.972(11)$ \\
\hline$\gamma\left({ }^{\circ}\right)$ & 90 & 90 & 90 & 90 & 90 \\
\hline Volume $/ \AA^{3}$ & $457.31(15)$ & $2327.3(3)$ & $2339.6(4)$ & $2328.2(3)$ & $1161.8(2)$ \\
\hline Z & 2 & 8 & 8 & 8 & 4 \\
\hline$\rho_{\text {calc }}\left(\mathrm{g} / \mathrm{cm}^{3}\right)$ & 4.611 & 4.755 & 4.670 & 4.647 & 4.668 \\
\hline $2 \Theta$ range for data collection $\left({ }^{\circ}\right)$ & $7.126-54.92$ & $5.7-61.33$ & $5.69-62.04$ & $5.70-50.00$ & $5.7-61.932$ \\
\hline Index ranges & $\begin{aligned}-29 & \leq \mathrm{h} \leq 27 \\
-3 & \leq \mathrm{k} \leq 4 \\
-4 & \leq 1 \leq 7\end{aligned}$ & $\begin{array}{r}-15 \leq \mathrm{h} \leq 16 \\
-8 \leq \mathrm{k} \leq 9 \\
-40 \leq 1 \leq 23\end{array}$ & $\begin{aligned}-16 & \leq \mathrm{h} \leq 16 \\
-6 & \leq \mathrm{k} \leq 9 \\
-33 & \leq 1 \leq 40\end{aligned}$ & $\begin{aligned}-14 & \leq \mathrm{h} \leq 14 \\
-8 & \leq \mathrm{k} \leq 7 \\
-34 & \leq 1 \leq 33\end{aligned}$ & $\begin{aligned}-9 & \leq \mathrm{h} \leq 7 \\
-38 & \leq \mathrm{k} \leq 32 \\
-9 & \leq 1 \leq 9\end{aligned}$ \\
\hline Reflections collected & 1018 & 5920 & 10,932 & 7368 & 6471 \\
\hline Independent reflections & 475 & 4494 & 4797 & 3597 & 4708 \\
\hline$R_{\text {int }}, R_{\text {sigma }}$ & $0.0171,0.0189$ & $0.0354,0.0397$ & $0.0396,0.0545$ & $0.0607,0.0571$ & $0.0278,0.0271$ \\
\hline Data/restraints/parameters & $475 / 31 / 53$ & $4494 / 127 / 255$ & $4797 / 1 / 136$ & $3597 / 1 / 135$ & $4708 / 211 / 216$ \\
\hline Goodness-of-fit on $\mathrm{F}^{2}$ & 1.202 & 1.074 & 1.145 & 1.608 & 1.125 \\
\hline Final $R$ indexes $[\mathrm{I}>=2 \sigma(\mathrm{I})]$ & $\begin{array}{c}R_{1}=0.0780 \\
\mathrm{w} R_{2}=0.1173\end{array}$ & $\begin{array}{c}R_{1}=0.0896 \\
w R_{2}=0.2586\end{array}$ & $\begin{array}{r}R_{1}=0.0884 \\
w R_{2}=0.2361\end{array}$ & $\begin{array}{r}R_{1}=0.1170 \\
\mathrm{w} R_{2}=0.3522\end{array}$ & $\begin{array}{c}R_{1}=0.0881 \\
w R_{2}=0.1802\end{array}$ \\
\hline Final $R$ indexes [all data] & $\begin{array}{c}R_{1}=0.0817 \\
w R_{2}=0.1197\end{array}$ & $\begin{array}{c}R_{1}=0.1009 \\
\mathrm{w} R_{2}=0.2728\end{array}$ & $\begin{array}{c}R_{1}=0.1311 \\
\mathrm{w} R_{2}=0.2941\end{array}$ & $\begin{array}{c}R_{1}=0.1286 \\
w R_{2}=0.3608\end{array}$ & $\begin{array}{c}R_{1}=0.0990 \\
\mathrm{w} R_{2}=0.1874\end{array}$ \\
\hline
\end{tabular}
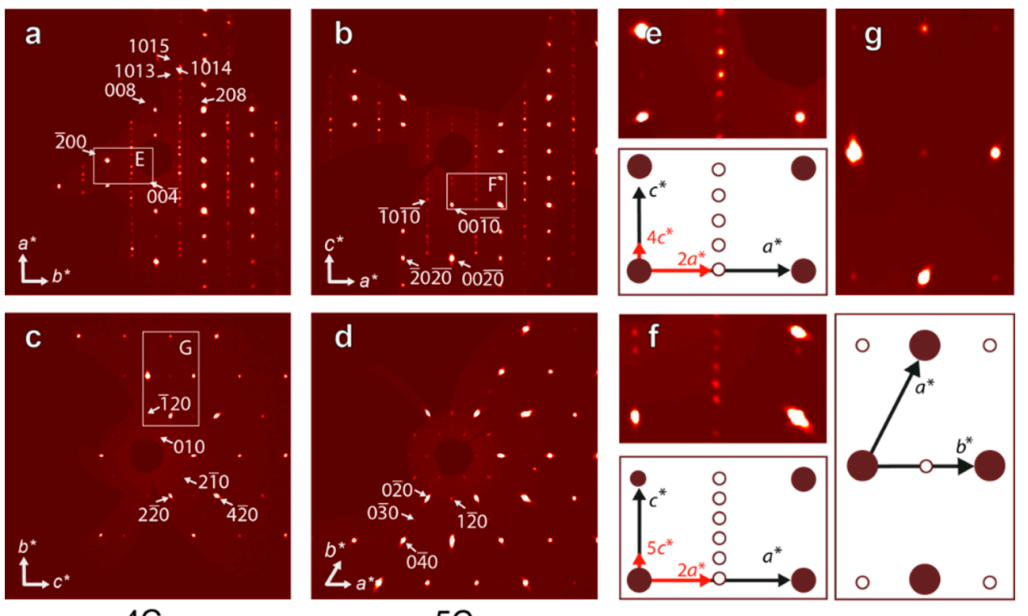

Figure 6. Reconstructed sections of reciprocal space obtained for $(h 0 l)$ and $(h k 0)$ sections for $1(\mathbf{a}, \mathbf{c})$ and 4 pyrrhotite samples $(\mathbf{b}, \mathbf{d})$ and enlarged fragments of these sections $(\mathbf{e}-\mathbf{g})$. For sample 1, there was used the transformation matrix [010 001 100]. White arrows and numbers indicate reflections and its indices. On corresponding schemas, large dark red circles and small unfilled circles belong to the hexagonal cell $(a=3.43, c=5.68 \AA)$ and supercell respectively; black and red arrows indicate subcell and supercell vectors respectively. 
The crystal structure of ferrimagnetic pyrrhotite $-4 \mathrm{C}, \mathrm{Fe}_{6.78} \mathrm{~S}_{8}$, was refined in the $\mathrm{Imm} 2$ space group. It differs from the previous refinements of crystal structure of stoichiometric $\mathrm{Fe}_{7} \mathrm{~S}_{8}$ in $\mathrm{C} 2 / c$ and $C 2$ space groups $[51,56]$ by distribution of vacancies in Fe sites (Figure 7) based on the observed differences in their chemical compositions. The Kovdor pyrrhotite-4C contains four independent iron sites with refined occupancies of $0.89,0.75,1$ and 0.75 for Fe1, Fe2, Fe3 and Fe4 respectively.

In the crystal structure of the pyrrhotite-5C with the $P 2_{1}$ symmetry, anomalously short distance $2.470 \AA$ A has been observed between $\mathrm{Fe} 2$ and $\mathrm{Fe} 4$ sites (Figure 8). There are two possible explanations for this fact: (1) one of these sites is vacant, while the second one is populated (their refined occupancies are 0.24 for the $\mathrm{Fe} 2$ site and 0.75 for the $\mathrm{Fe} 4$ site); (2) the Fe2-Fe4 interaction has at least partially bonding character. The same structural effect has been observed in [57].

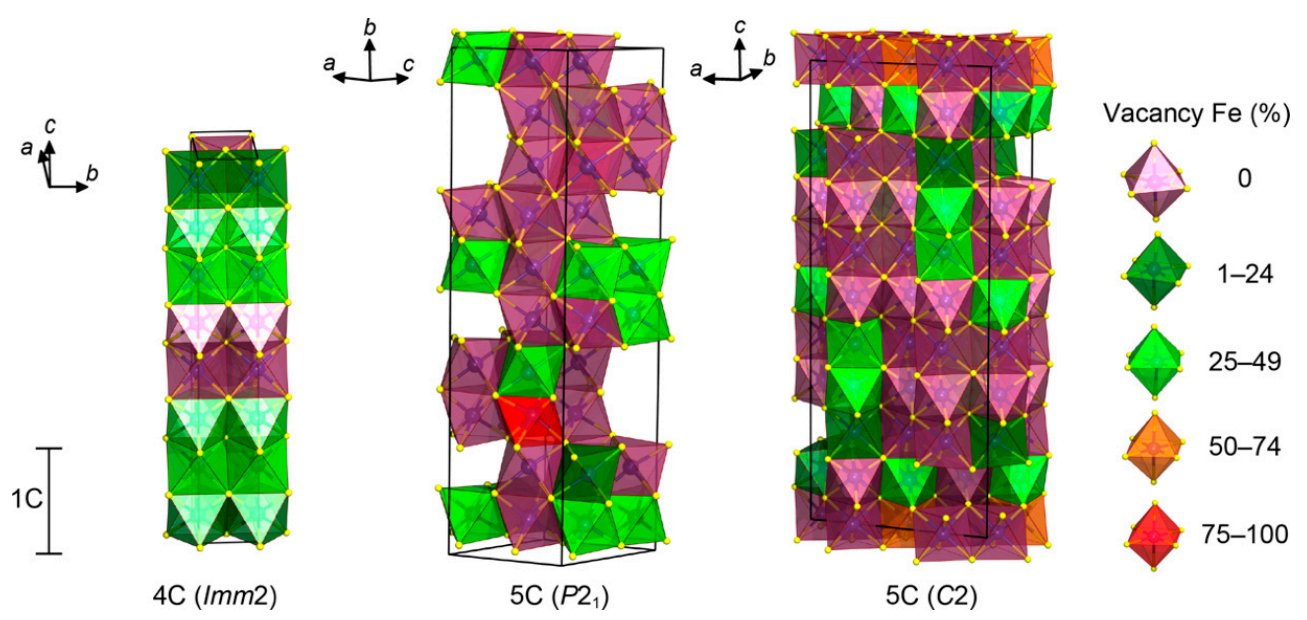

Figure 7. Three structural modifications of pyrrhotite from the Kovdor massif (for comparison, the transformation matrix [010 001 100] was used for 4C polytype).

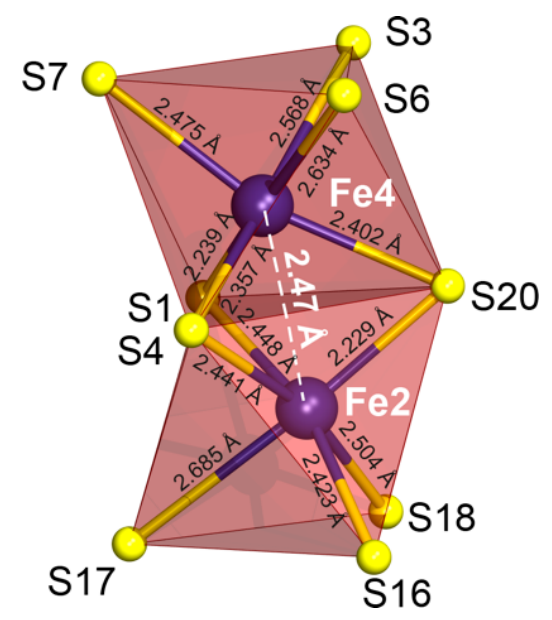

Figure 8. Local configuration around Fe2- and Fe4-centered octahedra in sample 5 crystal structure (pyrrhotite-5C with $P 2_{1}$ space group).

Most samples of the Kovdor pyrrhotite-5C are crystallized in C2 space group. Their chemical composition widely varies, $\mathrm{Fe}_{8.84-8.99} \mathrm{~S}_{10}$, which causes differences in occupancy of Fe-sites (Figure 9). From 6 to 9 iron sites (from 22 ones in C2 model) are observed. They have a different vacancy proportion ranging from $1 \%$ to $100 \%$. Such variability of $5 \mathrm{C}$ polytype can explain its domination in the Kovdor massif (see Figure 3). In samples 1-5, the mean $<\mathrm{Fe}-\mathrm{S}>$ distance ranges from 2.426 to $2.454 \AA$, and the expected elongation of bonds can be compensated by partial incorporation of $\mathrm{Fe}^{3+}$ in low-occupied sites [48,57]. 


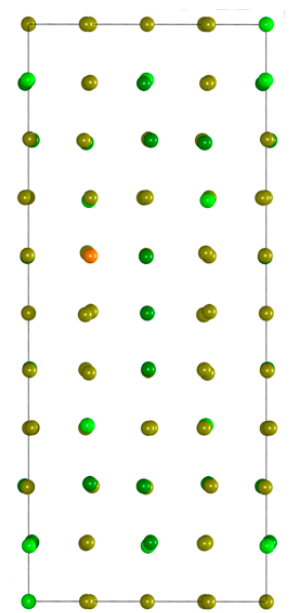

2

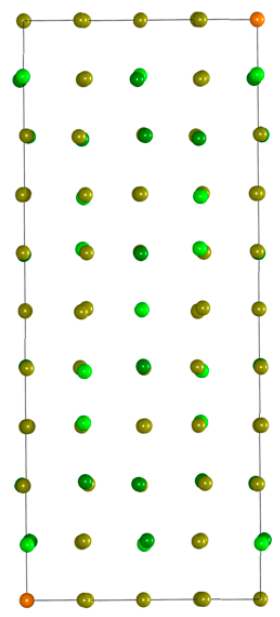

3

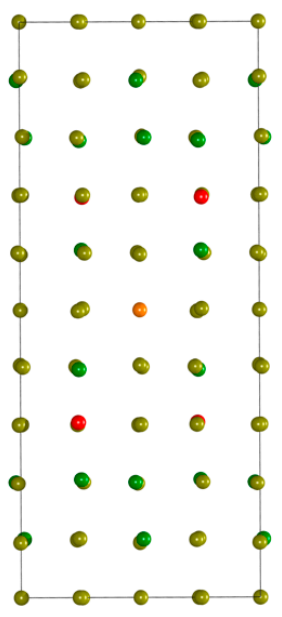

Vacancy Fe (\%)

C 0

(- 1-24

25-49

$50-74$

$75-100$

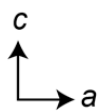

Figure 9. Arrangement of iron vacancies in pyrrhotite-5C (samples 2, 3 and 4). Sulfur atoms are omitted for clarity, unit cell is outlined.

Similar to nickel content in the rocks (see Table 2), the amount of $\mathrm{Ni}$ in pyrrhotite gradually decreases from host foidolite and diopsidite-glimmerite to marginal (apatite)-forsterite phoscorite, intermediate low-carbonate magnetite-rich phoscorite, calcite-rich phoscorite, phoscorite-related and vein calcite carbonatite, and then insignificantly increases in vein dolomite carbonatite and the related dolomite-magnetite-serpentine rock. In contrast, content of Co both in rock and pyrrhotite increases from host silicate rocks and marginal calcite-poor phoscorite to calcite-bearing phoscorite and phoscorite-related carbonatite and then slightly decreases in the vein carbonatites (Figure 4c). Correspondingly, Ni-dominant pyrrhotite is concentrated in the marginal zone of the phoscorite-carbonatite complex, Ni-Co-bearing pyrrhotite occurs in the intermediate zone, and Co-dominant pyrrhotite occupies the axial zone of the pipe (Figure $5 b$ ).

Almost all pyrrhotite grains contain exsolution inclusions of pentlandite, $\left(\mathrm{Ni}_{4.5} \mathrm{Fe}_{4.5}\right) \mathrm{S}_{8}$, or cobaltpentlandite, $\mathrm{Co}_{9} \mathrm{~S}_{8}$, and, much rarely, troilite, $\mathrm{FeS}$ :

$$
\begin{gathered}
\mathrm{Fe}_{11} \mathrm{~S}_{12} \rightarrow \mathrm{Fe}_{9} \mathrm{~S}_{10}+2 \mathrm{FeS} \text { and } \mathrm{Fe}_{9} \mathrm{~S}_{10} \rightarrow \mathrm{Fe}_{7} \mathrm{~S}_{8}+2 \mathrm{FeS} \\
9\left(\mathrm{Fe}_{8.5} \mathrm{Ni}_{0.5}\right) \mathrm{S}_{10} \rightarrow 9 \mathrm{Fe}_{7} \mathrm{~S}_{8}+\mathrm{Fe}_{9} \mathrm{~S}_{10}+\left(\mathrm{Fe}_{4.5} \mathrm{Ni}_{4.5}\right) \mathrm{S}_{8} \\
9\left(\mathrm{Fe}_{8} \mathrm{Co}\right) \mathrm{S}_{10} \rightarrow 9 \mathrm{Fe}_{7} \mathrm{~S}_{8}+\mathrm{Fe}_{9} \mathrm{~S}_{10}+\mathrm{Co}_{9} \mathrm{~S}_{8} .
\end{gathered}
$$

Troilite occurs only as lens-like lamellae along (001) planes of host pyrrhotite from marginal (apatite)-forsterite phoscorite (see Figure 5a) and, rarely, phoscorite-related carbonatite (Figure 10a). The host pyrrhotite is predominantly represented by its $4 \mathrm{C}$ modification in marginal (apatite)-forsterite phoscorite, and by $5 \mathrm{C}$ modification in axial phoscorite-related carbonatite. In host silicate rocks and vein calcite and dolomite carbonatites, troilite has not been found.

Exsolution inclusions of pentlandite in pyrrhotite occur mainly in host silicate rocks and (apatite)-forsterite phoscorite of the phoscorite-carbonatite complex marginal zone, and independent pentlandite grains (up to $120 \mu \mathrm{m}$ in diameter) occur rarely in (apatite)-forsterite phoscorite and dolomite-magnetite-serpentine rock. Pyrrhotite with inclusions of cobaltpentlandite dominates in the pipe axial carbonate-rich zone, while intermediate low-carbonate magnetite-rich phoscorite usually contains pyrrhotite with inclusions of both pentlandite and cobaltpentlandite with approximately equal proportions of $\mathrm{Co}$ and $\mathrm{Ni}-\mathrm{Fe}$. Exsolution pentlandite-cobaltpentlandite forms distinctive flame-like (up to $200 \mu \mathrm{m}$ long, Figure 2b) round or hexangular lamellar inclusions (up to $100 \mu \mathrm{m}$ in diameter and $10 \mu \mathrm{m}$ thick, Figures $2 \mathrm{a}$ and $10 \mathrm{~b}$ ) that predominantly grow along $\{0001\}$ planes of host pyrrhotite from boundaries of its grains and fissures. Sometimes, the oriented inclusions 
of pentlandite-cobaltpentlandite are found in pseudomorphs of pyrite, valleriite, carbonates (see Figure 10b) and secondary magnetite after pyrrhotite.
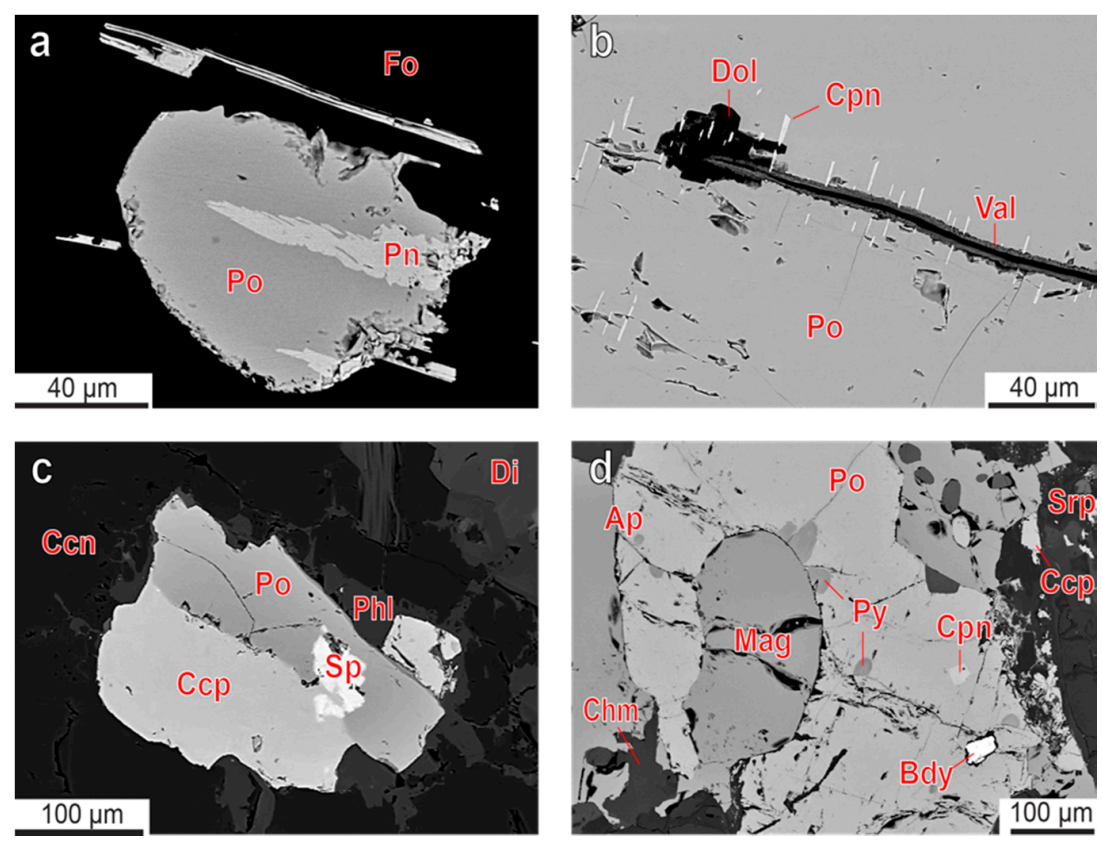

Figure 10. BSE-images of troilite exsolution inclusions ((a) phoscorite-related carbonatite 924/26.7), cobaltpentlandite ((b) CMAF-phoscorite 996/304.7), sphalerite ((c) diopsidite 1017/115.1) and pyrite ((d) CMAF-phoscorite 966/29) in pyrrhotite. Mineral abbreviations can be seen in Section 2.

Chemical composition of pentlandite-cobaltpentlandite varies in all possible ranges (Table 5). Increase of $\mathrm{Co} / \mathrm{Ni}$-ratio in pyrrhotite causes logarithmical growth of this ratio in exsolution pentlandite-cobaltpentlandite (Figure 11). In the sequence of rock formation, there is a gradual increase of Co content in pentlandite-cobaltpentlandite due to $\mathrm{Ni}$ and Fe (see Figure 4c), which causes corresponding spatial zonation of the phoscorite-carbonatite complex (see Figure 5c).

Table 5. Chemical composition of pentlandite-cobaltpentlandite (mean $\pm \mathrm{SD} / \mathrm{min}-\mathrm{max}$ ).

\begin{tabular}{|c|c|c|c|c|c|c|c|}
\hline \multirow{2}{*}{ Rock } & \multicolumn{2}{|c|}{ Host Rock } & \multicolumn{3}{|c|}{ Phoscorite and Related Carbonatite } & \multicolumn{2}{|c|}{ Vein Carbonatite } \\
\hline & Foidolite & Diopsidite & (Ap)-Fo & Low-Cb Mag-rich & Cal-rich & Cal & Dol \\
\hline$n$ & 6 & 24 & 13 & 51 & 67 & 17 & 8 \\
\hline S, wt \% & $\begin{array}{c}33 \pm 1 \\
32.34-34.80\end{array}$ & $\begin{array}{c}33 \pm 1 \\
27.51-34.73\end{array}$ & $\begin{array}{c}33.0 \pm 0.5 \\
32.06-33.74\end{array}$ & $\begin{array}{c}32.8 \pm 0.7 \\
31.84-35.24\end{array}$ & $\begin{array}{c}32.7 \pm 0.8 \\
31.61-36.12\end{array}$ & $\begin{array}{c}32.6 \pm 0.4 \\
31.80-33.57\end{array}$ & $\begin{array}{c}32.4 \pm 0.9 \\
30.64-33.66\end{array}$ \\
\hline $\mathrm{Fe}$ & $\begin{array}{c}26 \pm 9 \\
11.64-30.64\end{array}$ & $\begin{array}{c}28 \pm 3 \\
15.52-32.87\end{array}$ & $\begin{array}{c}23 \pm 7 \\
9.25-30.94\end{array}$ & $\begin{array}{c}14 \pm 7 \\
4.81-28.00\end{array}$ & $\begin{array}{c}13 \pm 8 \\
3.52-35.02\end{array}$ & $\begin{array}{c}9 \pm 3 \\
4.24-15.42\end{array}$ & $\begin{array}{c}17 \pm 9 \\
4.58-28.42\end{array}$ \\
\hline Co & $\begin{array}{c}10 \pm 20 \\
1.72-47.16\end{array}$ & $\begin{array}{c}10 \pm 10 \\
0.77-54.33\end{array}$ & $\begin{array}{c}20 \pm 20 \\
4.50-52.27\end{array}$ & $\begin{array}{c}40 \pm 10 \\
10.11-61.91\end{array}$ & $\begin{array}{c}50 \pm 20 \\
1.21-61.92\end{array}$ & $\begin{array}{c}57 \pm 4 \\
47.63-62.36\end{array}$ & $\begin{array}{c}30 \pm 20 \\
8.16-63.16\end{array}$ \\
\hline $\mathrm{Ni}$ & $\begin{array}{c}30 \pm 10 \\
8.86-34.53\end{array}$ & $\begin{array}{c}30 \pm 8 \\
2.65-37.12\end{array}$ & $\begin{array}{c}20 \pm 10 \\
5.11-34.47\end{array}$ & $\begin{array}{c}10 \pm 9 \\
0.7-30.14\end{array}$ & $\begin{array}{c}10 \pm 10 \\
0.62-32.96\end{array}$ & $\begin{array}{c}2 \pm 3 \\
0.25-10.26\end{array}$ & $\begin{array}{c}20 \pm 10 \\
3.94-32.21\end{array}$ \\
\hline $\mathrm{Ni}$, apfu & $\begin{array}{c}3 \pm 2 \\
1.20-4.64\end{array}$ & $\begin{array}{c}4 \pm 1 \\
0.42-5.01\end{array}$ & $\begin{array}{c}3 \pm 1 \\
0.68-4.64\end{array}$ & $\begin{array}{c}1 \pm 1 \\
0.09-3.93\end{array}$ & $\begin{array}{c}1 \pm 1 \\
0.08-4.31\end{array}$ & $\begin{array}{l}0.3 \pm 0.3 \\
0.03-1.36\end{array}$ & $\begin{array}{c}2 \pm 2 \\
0.53-4.24\end{array}$ \\
\hline $\mathrm{Fe}$ & $\begin{array}{c}4 \pm 1 \\
1.65-4.23\end{array}$ & $\begin{array}{l}3.9 \pm 0.4 \\
2.59-4.53\end{array}$ & $\begin{array}{l}3.2 \pm 0.9 \\
1.28-4.38\end{array}$ & $\begin{array}{l}1.9 \pm 0.9 \\
0.68-3.87\end{array}$ & $\begin{array}{c}2 \pm 1 \\
0.50-4.51\end{array}$ & $\begin{array}{l}1.2 \pm 0.4 \\
0.60-2.17\end{array}$ & $\begin{array}{l}0.65 \pm 4.07 \\
3.87-23.32\end{array}$ \\
\hline Co & $\begin{array}{c}2 \pm 3 \\
0.22-6.35\end{array}$ & $\begin{array}{c}1 \pm 2 \\
0.10-8.60\end{array}$ & $\begin{array}{c}3 \pm 2 \\
0.60-6.88\end{array}$ & $\begin{array}{c}6 \pm 2 \\
1.31-8.38\end{array}$ & $\begin{array}{c}6 \pm 2 \\
0.15-8.26\end{array}$ & $\begin{array}{l}7.6 \pm 0.6 \\
6.30-8.45\end{array}$ & $\begin{array}{c}4 \pm 3 \\
1.07-8.52\end{array}$ \\
\hline S & 8 & 8 & 8 & 8 & 8 & 8 & 8 \\
\hline
\end{tabular}



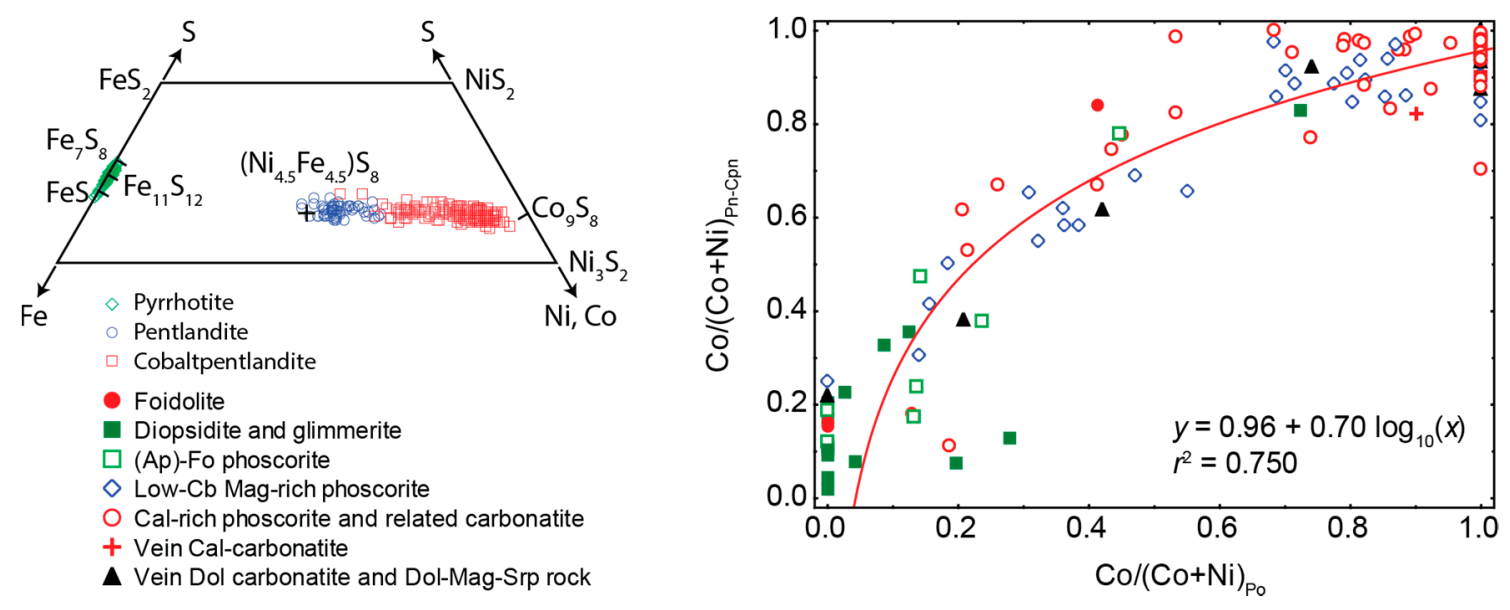

Figure 11. Compositions of host pyrrhotite and exsolution pentlandite-cobaltpentlandite.

On the $\mathrm{M}_{9} \mathrm{~S}_{8}$ plane of the Fe-Ni-Co-S tetrahedron (Figure 12), chemical compositions of pentlandite are concentrated within the field of the solid-solution stability at $\geq 200{ }^{\circ} \mathrm{C}$ [58]. Chemical compositions of cobaltpentlandite correspond to the $\mathrm{Fe}_{4.5} \mathrm{Ni}_{4.5} \mathrm{~S}-\mathrm{Co}_{9} \mathrm{~S}_{8}$ trend, whereas most samples from host silicate rocks, marginal forsterite-dominant and intermediate low-carbonate magnetite-rich phoscorite are within the stability field at $300-400{ }^{\circ} \mathrm{C}$, and most samples from axial carbonate rich phoscorite and carbonatites are within the stability field at $200-400{ }^{\circ} \mathrm{C}$.

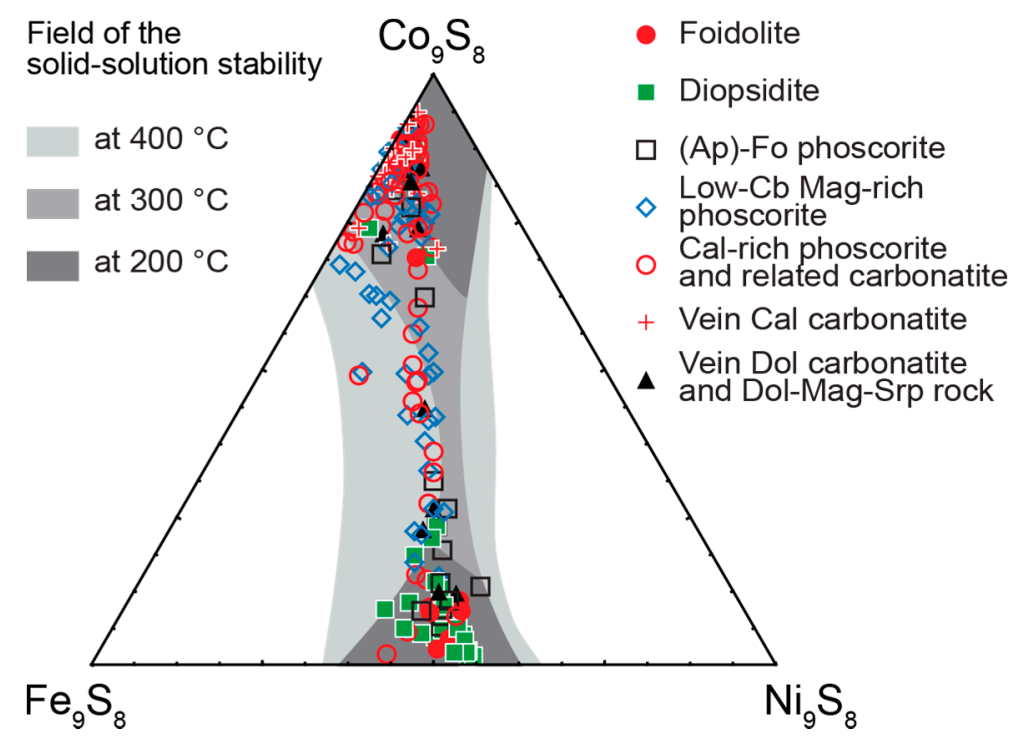

Figure 12. Relationship between composition of the Kovdor's pentlandite-cobaltpentlandite and fields of pentlandite-cobaltpentlandite stability after [58].

Comparatively rare exsolution sphalerite occurs as rounded, irregularly shaped, cross- and butterfly-like inclusions (up to $100 \mu \mathrm{m}$, Figure 10c) in pyrrhotite from any types of rocks. Sphalerite together with chalcopyrite also form rims (up to $120 \mu \mathrm{m}$ thick) around pyrrhotite grains in dolomite-magnetite-serpentine rock. Since chemical composition of exsolution sphalerite (Table 6) at temperature below $500{ }^{\circ} \mathrm{C}$ depends on pressure only [59-61], we calculate the pressure using the following equation [62]:

$$
\mathrm{FeS}_{\mathrm{Sp}}=20.53-1.313 P+0.0271 P^{2},
$$

where $\mathrm{FeS}_{\mathrm{Sp}}$ is in $\mathrm{mol} \%$, and $P$ is in kbar. The results (see Table 6) shows gradual pressure decrease from $4 \mathrm{kbar}$ in marginal (apatite)-forsterite phoscorite to $2 \mathrm{kbar}$ in axial carbonate-rich phoscorite and 
phoscorite-related carbonatite, and then again growth to $4 \mathrm{kbar}$ in vein calcite carbonatite, and decrease to $2 \mathrm{kbar}$ in vein dolomite carbonatite (i.e., decrease by 2 kbar from earlier to the latest rock within both pipe and vein series). It is necessary to note similar behavior of oxygen fugacity [26] estimated with the $\mathrm{Fe}^{2+} \mathrm{Ti}-\mathrm{Fe}^{3+}{ }_{2}$ magnetite-ilmenite exchange geothermometer/oxometer of Ghiorso and Evans [63].

Table 6. Chemical composition of sphalerite inclusions in pyrrhotite (mean $\pm \mathrm{SD} / \mathrm{min}-\mathrm{max}$ ) and pressure of their formation estimated with a sphalerite-pyrite-pyrrhotite geobarometer [62].

\begin{tabular}{|c|c|c|c|c|c|c|c|}
\hline \multirow{2}{*}{ Rock } & \multicolumn{2}{|c|}{ Host Rock } & \multicolumn{3}{|c|}{ Phoscorite and Related Carbonatite } & \multicolumn{2}{|c|}{ Vein Carbonatite } \\
\hline & Foidolite & Diopsidite & (Ap)-Fo & Low-Cb Mag-rich & Cal-rich & Cal & Dol \\
\hline$n$ & 3 & 13 & 3 & 14 & 24 & 9 & 17 \\
\hline $\mathrm{S}, \mathrm{wt} \%$ & $\begin{array}{c}31.6 \pm 0.6 \\
31.02-32.22\end{array}$ & $\begin{array}{c}32.0 \pm 0.6 \\
30.96-32.83\end{array}$ & $\begin{array}{c}32 \pm 1 \\
30.43-32.88\end{array}$ & $\begin{array}{c}31.7 \pm 0.9 \\
29.60-33.22\end{array}$ & $\begin{array}{c}31.7 \pm 0.9 \\
29.78-33.86\end{array}$ & $\begin{array}{c}31.5 \pm 0.7 \\
30.70-32.59\end{array}$ & $\begin{array}{c}32 \pm 1 \\
27.60-33.44\end{array}$ \\
\hline $\mathrm{Mn}$ & $\begin{array}{c}0.5 \pm 0.5 \\
<0.01-0.95\end{array}$ & $\begin{array}{c}0.3 \pm 0.5 \\
<0.01-1.44\end{array}$ & $\begin{array}{l}0.8 \pm 0.2 \\
0.57-0.99\end{array}$ & $\begin{array}{c}0.6 \pm 0.9 \\
<0.01-3.51\end{array}$ & $\begin{array}{c}1 \pm 1 \\
<0.01-6.17\end{array}$ & $\begin{array}{c}1 \pm 1 \\
<0.01-2.89\end{array}$ & $\begin{array}{c}0.5 \pm 0.5 \\
<0.01-1.52\end{array}$ \\
\hline $\mathrm{Fe}$ & $\begin{array}{c}10 \pm 1 \\
9.51-11.51\end{array}$ & $\begin{array}{c}9 \pm 1 \\
6.18-11.33\end{array}$ & $\begin{array}{l}8.8 \pm 0.9 \\
8.13-9.79\end{array}$ & $\begin{array}{c}10 \pm 2 \\
6.67-15.06\end{array}$ & $\begin{array}{c}10 \pm 2 \\
5.51-15.82\end{array}$ & $\begin{array}{c}9 \pm 2 \\
5.69-13.23\end{array}$ & $\begin{array}{c}10 \pm 2 \\
5.86-12.77\end{array}$ \\
\hline Co & $<0.01$ & $<0.01$ & $\begin{array}{c}0.1 \pm 0.2 \\
<0.01-0.40\end{array}$ & $\begin{array}{c}0.2 \pm 0.3 \\
<0.01-0.99\end{array}$ & $\begin{array}{c}0.1 \pm 0.2 \\
<0.01-0.63\end{array}$ & $\begin{array}{c}0.2 \pm 0.4 \\
<0.01-1.15\end{array}$ & $\begin{array}{c}0.2 \pm 0.3 \\
<0.01-1.04\end{array}$ \\
\hline $\mathrm{Ni}$ & $<0.01$ & $<0.01$ & $<0.01$ & $<0.01$ & $\begin{array}{l}0.01 \pm 0.03 \\
<0.01-0.13\end{array}$ & $<0.01$ & $<0.01$ \\
\hline $\mathrm{Zn}$ & $\begin{array}{c}56 \pm 1 \\
54.52-57.01\end{array}$ & $\begin{array}{c}58 \pm 2 \\
54.04-61.50\end{array}$ & $\begin{array}{c}58 \pm 2 \\
56.78-60.27\end{array}$ & $\begin{array}{c}57 \pm 3 \\
51.71-62.99\end{array}$ & $\begin{array}{c}54 \pm 5 \\
42.41-63.11\end{array}$ & $\begin{array}{c}57 \pm 5 \\
49.17-62.79\end{array}$ & $\begin{array}{c}57 \pm 3 \\
52.99-62.12\end{array}$ \\
\hline $\mathrm{Cd}$ & $\begin{array}{c}2 \pm 1 \\
0.73-3.37\end{array}$ & $\begin{array}{c}1 \pm 1 \\
<0.01-3.57\end{array}$ & $<0.01$ & $\begin{array}{c}0.6 \pm 0.8 \\
<0.01-2.98\end{array}$ & $\begin{array}{c}3 \pm 3 \\
<0.01-10.01\end{array}$ & $\begin{array}{c}2 \pm 2 \\
<0.01-5.96\end{array}$ & $\begin{array}{c}0.1 \pm 0.3 \\
<0.01-1.03\end{array}$ \\
\hline $\mathrm{Zn}$, apfu & $\begin{array}{c}0.86 \pm 0.01 \\
0.85-0.87\end{array}$ & $\begin{array}{c}0.89 \pm 0.04 \\
0.81-0.95\end{array}$ & $\begin{array}{c}0.90 \pm 0.06 \\
0.86-0.97\end{array}$ & $\begin{array}{c}0.89 \pm 0.07 \\
0.77-1.04\end{array}$ & $\begin{array}{c}0.83 \pm 0.09 \\
0.63-0.99\end{array}$ & $\begin{array}{c}0.88 \pm 0.09 \\
0.75-1.00\end{array}$ & $\begin{array}{c}0.88 \pm 0.07 \\
0-0\end{array}$ \\
\hline $\mathrm{Fe}$ & $\begin{array}{c}0.19 \pm 0.02 \\
0.18-0.21\end{array}$ & $\begin{array}{c}0.16 \pm 0.03 \\
0.11-0.20\end{array}$ & $\begin{array}{c}0.16 \pm 0.02 \\
0.14-0.17\end{array}$ & $\begin{array}{c}0.17 \pm 0.04 \\
0.12-0.28\end{array}$ & $\begin{array}{c}0.19 \pm 0.04 \\
0.10-0.27\end{array}$ & $\begin{array}{c}0.17 \pm 0.05 \\
0.11-0.25\end{array}$ & $\begin{array}{c}0.19 \pm 0.04 \\
0.11-0.27\end{array}$ \\
\hline Mn & $\begin{array}{c}0.01 \pm 0.01 \\
0.00-0.02\end{array}$ & $\begin{array}{c}0.01 \pm 0.01 \\
0.00-0.03\end{array}$ & $\begin{array}{c}0.01 \\
0.01-0.02\end{array}$ & $\begin{array}{c}0.01 \pm 0.02 \\
0.00-0.06\end{array}$ & $\begin{array}{c}0.03 \pm 0.02 \\
0.00-0.11\end{array}$ & $\begin{array}{c}0.01 \pm 0.02 \\
0.00-0.05\end{array}$ & $\begin{array}{c}0.01 \pm 0.01 \\
0.00-0.03\end{array}$ \\
\hline $\mathrm{Cd}$ & $\begin{array}{c}0.02 \pm 0.01 \\
0.01-0.03\end{array}$ & $\begin{array}{c}0.01 \pm 0.01 \\
0.00-0.03\end{array}$ & - & $\begin{array}{c}0.01 \pm 0.01 \\
0.00-0.03\end{array}$ & $\begin{array}{c}0.03 \pm 0.03 \\
0.00-0.09\end{array}$ & $\begin{array}{c}0.02 \pm 0.02 \\
0.00-0.05\end{array}$ & $\begin{array}{c}0.00 \\
0.00-0.01\end{array}$ \\
\hline Co & - & - & $\begin{array}{c}0.00 \\
0.00-0.01\end{array}$ & $\begin{array}{c}0.00 \pm 0.01 \\
0.00-0.02\end{array}$ & $\begin{array}{c}0.00 \\
0.00-0.01\end{array}$ & $\begin{array}{c}0.00 \pm 0.01 \\
0.00-0.02\end{array}$ & $\begin{array}{c}0.00 \pm 0.01 \\
0.00-0.02\end{array}$ \\
\hline S & 1 & 1 & 1 & 1 & 1 & 1 & 1 \\
\hline$P$, kbar & $\begin{array}{c}2.2 \pm 0.1 \\
2.1-2.3\end{array}$ & $\begin{array}{c}4 \pm 2 \\
0.5-8.9\end{array}$ & $\begin{array}{c}4 \pm 1 \\
2.6-5.4\end{array}$ & $\begin{array}{c}4 \pm 2 \\
1.1-7.6\end{array}$ & $\begin{array}{c}3 \pm 2 \\
0.4-9.9\end{array}$ & $\begin{array}{c}5 \pm 3 \\
1.8-9.4\end{array}$ & $\begin{array}{c}3 \pm 2 \\
0.2-9.5\end{array}$ \\
\hline
\end{tabular}

In intermediate low-carbonate magnetite-rich and, especially, axial calcite-rich phoscorite and phoscorite-related carbonatite, there are grains of pyrrhotite-6C with rounded inclusions of pyrite (up to $100 \mu \mathrm{m}$ in diameter, Figure 10d) that can be regarded as products of exsolution of sulfur-rich pyrrhotite-4C and $-5 \mathrm{C}[62,64,65]$ :

$$
\begin{gathered}
4 \mathrm{Fe}_{7} \mathrm{~S}_{8} \leftrightarrow 3 \mathrm{Fe}_{9} \mathrm{~S}_{10}+\mathrm{FeS}_{2,} \\
5 \mathrm{Fe}_{7} \mathrm{~S}_{8} \leftrightarrow 4 \mathrm{Fe}_{11} \mathrm{~S}_{12}+\mathrm{FeS}_{2} \text {, or } \\
5 \mathrm{Fe}_{9} \mathrm{~S}_{10} \leftrightarrow \mathrm{Fe}_{11} \mathrm{~S}_{12}+\mathrm{FeS}_{2} .
\end{gathered}
$$

In this case, distribution of impurities between the coexisting pyrrhotite and pyrite depends on temperature: with temperature decrease, the impurities undergo redistribution from pyrite into pyrrhotite, and vice versa [66]. Constant presence of cobalt impurity in the Kovdor pyrite-pyrrhotite pairs (Table 7) allows us to estimate temperature of their formation using the Co-Fe exchange pyrite-pyrrhotite geothermometer: 


$$
T=\frac{1000}{1.907-0.538 \log _{10} K_{D}^{\mathrm{Co}}}
$$

where $T$ is temperature in $K, K_{D}{ }^{\mathrm{Co}}=\left(\mathrm{Co}_{\text {at.\%}} / \mathrm{Fe}_{\text {at.\% }}\right)_{\mathrm{Po}}:\left(\mathrm{Co}_{a t . \%} / \mathrm{Fe}_{\text {at.\% }}\right)_{\mathrm{Py}}[66]$. Our calculations showed (see Table 7) that temperature of Co equilibration between pyrite and pyrrhotite increases from $170{ }^{\circ} \mathrm{C}$ in intermediate low-carbonate magnetite-rich phoscorite to $300{ }^{\circ} \mathrm{C}$ in axial carbonate-rich phoscorite, and then decrease to $230{ }^{\circ} \mathrm{C}$ in vein dolomite carbonatite.

It is necessarily to note that pyrrhotite- $4 \mathrm{C}$ may become stable at about $140{ }^{\circ} \mathrm{C}$ in nature [67], while $6 \mathrm{C}$ and $5 \mathrm{C}$ superstructures can be formed at temperatures below approx. $60^{\circ} \mathrm{C}$ [62]. Therefore, in natural rock sequence, the ratio of pyrrhotite- $5 C+6 C$ to pyrrhotite- $4 C$ (see Figure $4 a, b$ ) gradually increases due to the gradual decrease of the pyrrhotite superstructure formation temperature. These hypotheses are in good agreement with the results of calcite-dolomite and ilmenite-magnetite geothermometry for this rock sequence [26], where the average temperature of the mineral equilibration gradually decreases from $500{ }^{\circ} \mathrm{C}$ to $400{ }^{\circ} \mathrm{C}$ for carbonates and from $500{ }^{\circ} \mathrm{C}$ to $300{ }^{\circ} \mathrm{C}$ for oxides.

Table 7. Chemical composition of pyrite inclusions in pyrrhotite (mean $\pm \mathrm{SD} / \mathrm{min}-\mathrm{max}$ ), and temperature of their formation estimated with a Co-exchange pyrite-pyrrhotite geothermometer [66].

\begin{tabular}{cccc}
\hline Rock & Low-Cb Mag-Rich Phoscorite & Cal-Rich Phoscorite/Carbonatite & Dol-Carbonatite \\
\hline$n$ & 2 & 8 & 2 \\
$\mathrm{~S}, \mathrm{wt} \%$ & $52.4 \pm 0.6 / 51.94-52.80$ & $53.0 \pm 0.2 / 52.76-53.25$ & $53.1 \pm 0.2 / 52.97-53.30$ \\
$\mathrm{Fe}$ & $48 \pm 1 / 47.86-48.65$ & $46.8 \pm 0.9 / 45.52-48.51$ & $46.1 \pm 0.2 / 45.93-46.27$ \\
$\mathrm{Co}$ & $0.4 \pm 0.2 / 0.26-0.49$ & $0.1 \pm 0.2 /<0.01-0.01$ & $0.8 \pm 0.6 / 0.35-1.21$ \\
$\mathrm{Ni}$ & $<0.01$ & $0.03 \pm 0.05 /<0.01-0.13$ & $0.02 \pm 0.01 / 0.02-0.03$ \\
$\mathrm{Fe}$, apfu & $1.05 \pm 0.04 / 1.02-1.08$ & $1.02 \pm 0.02 / 0.98-1.05$ & $1.00 \pm 0.01 / 0.99-1.00$ \\
$\mathrm{Co}$ & 0.01 & $0.00 / 0.00-0.01$ & $0.02 \pm 0.01 / 0.01-0.03$ \\
$\mathrm{~S}$ & 2 & 2 & 2 \\
${ }^{\circ},{ }^{\circ} \mathrm{C}$ & $170 \pm 20 / 159-188$ & $300 \pm 100 / 235-444$ & $170 \pm 90 / 106-228$ \\
\hline
\end{tabular}

Besides exsolution inclusions of troilite, pentlandite-cobaltpentlandite, sphalerite and pyrite, there are unit inclusions of galena, mackinawite, clausthalite, violarite, hessite, moncheite and petzite (Table 8) in pyrrhotite grains. Mackinawite is a typical mineral for axial calcite-rich phoscorite and phoscorite-related carbonatite, where it forms equant or wedge-shaped inclusions (up to $100 \mu \mathrm{m}$ long) in pyrrhotite and, especially, chalcopyrite. Violarite is found together with pentlandite in dolomite-magnetite-serpentine rock as lens-like inclusions (up to $30 \mu \mathrm{m}$ long and $2 \mu \mathrm{m}$ thick) oriented along the $\{0001\}$ planes of host pyrrhotite. Both these minerals are not independent from pyrrhotite. Galena forms rounded inclusions (up to $20 \mu \mathrm{m}$ in diameter) in peripheral parts of pyrrhotite grains and pyrrhotite-chalcopyrite boundaries.

Table 8. Chemical composition of characteristic inclusions in pyrrhotite grains (wt \%/apfu).

\begin{tabular}{|c|c|c|c|}
\hline Mineral & Mck & Vlt & Cls \\
\hline Sample & $\mathrm{K}-02-124$ & $74 / 67.2$ & $73 / 205.8$ \\
\hline Rock & CM-phoscorite & $\begin{array}{l}\text { Mag-Dol-Srp } \\
\text { rock }\end{array}$ & $\begin{array}{c}\text { Vein } \\
\text { Cal-carbonatite }\end{array}$ \\
\hline S & $35.61 / 8.00$ & $43.31 / 4.00$ & bd \\
\hline $\mathrm{Mn}$ & bd & bd & bd \\
\hline $\mathrm{Fe}$ & $58.27 / 7.52$ & $16.99 / 0.90$ & bd \\
\hline Co & $0.94 / 0.12$ & $13.33 / 0.67$ & $\mathrm{bd}$ \\
\hline $\mathrm{Ni}$ & $5.56 / 0.68$ & $26.40 / 1.33$ & $\mathrm{bd}$ \\
\hline $\mathrm{Zn}$ & bd & bd & bd \\
\hline Se & $b d$ & bd & $26.82 / 1.00$ \\
\hline $\mathrm{Cd}$ & $\mathrm{bd}$ & $\mathrm{bd}$ & bd \\
\hline $\mathrm{Pb}$ & bd & bd & 73.98/1.05 \\
\hline Total & $100.38 / 16.32$ & $100.03 / 6.90$ & $100.80 / 2.05$ \\
\hline
\end{tabular}


Table 8. Cont

\begin{tabular}{cccc}
\hline Mineral & Hss & Mch & Ptz \\
\hline Sample & & $931 / 341.2$ \\
Rock & & Diopsidite & \\
$\mathrm{Ag}$ & $56.57 / 1.97$ & bd & $37.07 / 2.84$ \\
$\mathrm{Te}$ & $34.04 / 1.00$ & $44.54 / 1.54$ & $30.84 / 2.00$ \\
$\mathrm{Pd}$ & $\mathrm{bd}$ & $8.38 / 0.35$ & $\mathrm{bd}$ \\
$\mathrm{Pt}$ & $\mathrm{bd}$ & $25.40 / 0.58$ & $\mathrm{bd}$ \\
$\mathrm{Au}$ & $\mathrm{bd}$ & $\mathrm{bd}$ & $17.93 / 0.75$ \\
$\mathrm{~Pb}$ & $8.91 / 0.16$ & $\mathrm{bd}$ & $14.40 / 0.58$ \\
$\mathrm{Bi}$ & $\mathrm{bd}$ & $21.68 / 0.46$ & $\mathrm{bd}$ \\
Total & $99.52 / 3.13$ & $100.00 / 2.93$ & $100.24 / 6.17$ \\
\hline
\end{tabular}

In nepheline-bearing diopsidite, pyrrhotite contains tabular inclusions of moncheite (up to $15 \mu \mathrm{m}$ in diameter and $4 \mu \mathrm{m}$ thick), and irregularly shaped polyphase inclusions of hessite, petzite, galena and clausthalite (up to $6 \mu \mathrm{m}$ in diameter). All these inclusions may result from pyrrhotite self-cleaning from the corresponding impurities during rock cooling.

Under the influence of low-temperature hydrothermal solutions, pyrrhotite- $4 \mathrm{C}$ (often) and pyrrhotite-5C (rarely) can be replaced by pyrite, marcasite, valleriite, djerfisherite, pyrite and goethite (Table 9):

$$
\begin{gathered}
4 \mathrm{Po}+10 \mathrm{H}_{2} \mathrm{O}+15 \mathrm{O}_{2}=24 \mathrm{Py}+20 \mathrm{Ght}, \\
\mathrm{Po}+9 \mathrm{Mgs}+9 \mathrm{H}_{2} \mathrm{O}+\mathrm{Fe}^{2+}=3 \mathrm{Val}+9 \mathrm{CO}_{2}, \\
13 \mathrm{Po}+6 \mathrm{NaCl}+36 \mathrm{KCl}+7 \mathrm{Fe}^{2+}=6 \mathrm{Djf}, \\
\mathrm{Po}+24 \mathrm{O}_{2}+12 \mathrm{Ba}^{2+}=12 \mathrm{Brt}+11 \mathrm{Fe}^{2+}, \text { etc. }
\end{gathered}
$$

where Brt is barite, $\mathrm{BaSO}_{4}$; Djf—djerfisherite, $\mathrm{K}_{6} \mathrm{NaFe}_{25} \mathrm{~S}_{26} \mathrm{Cl}$; $\mathrm{Gth}$-goethite, $\mathrm{FeO}(\mathrm{OH})$; $\mathrm{Mgs}$-magnesite, $\mathrm{MgCO}_{3} ; \mathrm{Po}$ - pyrrhotite, $\mathrm{Fe}_{11} \mathrm{~S}_{12} ; \mathrm{Py}$ - pyrite, $\mathrm{FeS}_{2}$ and Val—valleriite, $\mathrm{Mg}_{3} \mathrm{Fe}_{4} \mathrm{~S}_{4}(\mathrm{OH})_{6}$.

Pyrite and other secondary minerals form partial to complete pseudomorphs after pyrrhotite (Figure 13), which are mostly spread within ring-like stockwork of vein calcite carbonatite and linear zone of vein dolomite carbonatite (see Figure 1), and also in well-shaped crystals in surrounding voids and fissures. In particular, pyrite forms cubic to pentagonal-dodecahedral crystals (up to $20 \mathrm{~cm}$ in diameter); marcasite composes sheaf-like aggregates of flattened prismatic crystals (up to $3 \mathrm{~mm}$ long);

\begin{tabular}{|c|c|c|c|c|c|}
\hline Mineral & Py & Mrc & Djf & Val & Brt \\
\hline Sample & $1011 / 79 / 6$ & K-96-19-1 & $1004 / 656.5$ & K-051 & $941 / 41.5$ \\
\hline Rock & AF-phoscorite & Dol-carbonatite & Cal-carbonatite & Dol-carbonatite & MAF-foscorite \\
\hline $\mathrm{Mg}$ & bd & bd & bd & $11.08 / 2.53$ & bd \\
\hline $\mathrm{Al}$ & bd & bd & $\mathrm{bd}$ & $0.67 / 0.14$ & bd \\
\hline $\mathrm{S}$ & $53.05 / 2.00$ & $53.34 / 2.00$ & $32.86 / 26.00$ & $23.16 / 4.00$ & $13.65 / 1.00$ \\
\hline $\mathrm{Cl}$ & bd & bd & $1.43 / 1.02$ & bd & bd \\
\hline $\mathrm{K}$ & $\mathrm{bd}$ & $\mathrm{bd}$ & $9.33 / 6.05$ & $\mathrm{bd}$ & bd \\
\hline $\mathrm{Ca}$ & bd & bd & bd & bd & $0.37 / 0.02$ \\
\hline $\mathrm{Fe}$ & $46.19 / 1.00$ & $46.79 / 1.01$ & $35.21 / 15.99$ & $31.81 / 3.15$ & bd \\
\hline $\mathrm{Co}$ & $0.39 / 0.01$ & bd & $0.03 / 0.01$ & bd & $\mathrm{bd}$ \\
\hline $\mathrm{Ni}$ & $0.05 / 0.00$ & $b d$ & $0.05 / 0.02$ & $2.93 / 0.28$ & $\mathrm{bd}$ \\
\hline $\mathrm{Cu}$ & bd & $b d$ & $21.52 / 8.59$ & $9.23 / 0.80$ & bd \\
\hline $\mathrm{Sr}$ & $b d$ & $b d$ & bd & bd & $0.87 / 0.02$ \\
\hline $\mathrm{Ba}$ & bd & bd & bd & bd & $57.02 / 0.96$ \\
\hline Total & $99.68 / 3.01$ & $100.13 / 3.01$ & $100.43 / 57.70$ & $78.88 / 10.90$ & $71.91 / 2.00$ \\
\hline
\end{tabular}
valleriite and tochilinite, $6 \mathrm{Fe} 0.9 \mathrm{~S} \cdot 5 \mathrm{Mg}(\mathrm{OH})_{2}$, occur as twisted platy crystals (up to $4 \mathrm{~mm}$ in diameter); and barite forms well shaped prismatic crystals (up to $4 \mathrm{~cm}$ long).

Table 9. Chemical composition of characteristic products of pyrrhotite alteration (wt \%/apfu).

In addition, $\mathrm{Fe}^{2+}$ and $\mathrm{Co}^{2+}$ cations resulted from low-temperature hydrothermal alteration of pyrrhotite react with $\left(\mathrm{PO}_{4}\right)^{3-}$ and $\left(\mathrm{CO}_{3}\right)^{2-}$ anions, and form late hydrothermal 
phosphates and carbonates: mitridatite, $\left(\mathrm{Ca}_{1.72} \mathrm{Fe}^{2+}{ }_{0.02}\right)_{\Sigma 1.74} \mathrm{Fe}^{3+}{ }_{3.10}\left[\mathrm{P}_{3.04} \mathrm{O}_{12}\right] \mathrm{O}_{2} \cdot 3 \mathrm{H}_{2} \mathrm{O}$, strengite, $\mathrm{Fe}^{3+}{ }_{0.99}\left[\mathrm{P}_{1.01} \mathrm{O}_{4}\right] \cdot 2 \mathrm{H}_{2} \mathrm{O}$, gladiusite, $\left(\mathrm{Fe}^{2+}{ }_{2.02} \mathrm{Mg}_{1.61} \mathrm{Mn}_{0.06}\right)_{\Sigma 3.69} \mathrm{Fe}^{3+}{ }_{2.17}\left[\mathrm{P}_{1.02} \mathrm{O}_{4}\right](\mathrm{OH})_{11} \cdot \mathrm{H}_{2} \mathrm{O}$, baricite, $\left(\mathrm{Mg}_{1.75} \mathrm{Fe}_{1.18}\right)_{\Sigma 2.93}\left[\mathrm{P}_{2.03} \mathrm{O}_{8}\right] \cdot 7 \mathrm{H}_{2} \mathrm{O}$, vivianite, $\left(\mathrm{Fe}_{2.88} \mathrm{Mg}_{0.02}\right)_{\Sigma 2.90}\left[\mathrm{P}_{2.04} \mathrm{O}_{8}\right] \cdot 8 \mathrm{H}_{2} \mathrm{O}$, pakhomovskyite, $\left(\mathrm{Co}_{2.38} \mathrm{Mg}_{0.38} \mathrm{Mn}_{0.17} \mathrm{Ni}_{0.04} \mathrm{Fe}^{2+}{ }_{0.03}\right)_{\Sigma 2.99}\left[\mathrm{P}_{2.01} \mathrm{O}_{8}\right] \cdot 8 \mathrm{H}_{2} \mathrm{O}$, siderite, $\left(\mathrm{Fe}_{0.97} \mathrm{Ca}_{0.02} \mathrm{Mg}_{0.01}\right)_{\Sigma 1.00}\left[\mathrm{CO}_{3}\right]$, and pyroaurite $\left(\mathrm{Mg}_{5.59} \mathrm{Fe}^{2+}{ }_{0.27}\right)_{\Sigma 5.86}\left(\mathrm{Fe}^{3+}{ }_{1.92} \mathrm{Al}_{0.08}\right)_{2.00}(\mathrm{OH})_{16}\left(\mathrm{CO}_{3}\right)_{0.86} \cdot 4 \mathrm{H}_{2} \mathrm{O}[11,33,35,68-70]$. In particular, pakhomovskyite and gladiusite together with pyrite precipitated on walls of leached fissures in dolomite carbonatite vein (see Figure $5 b, c$ ) as a result of the following approximate reaction [35]:

$$
3 \mathrm{Po}+32 \mathrm{H}_{2} \mathrm{O}+4\left(\mathrm{PO}_{4}\right)^{3-}=18 \mathrm{Py}+\mathrm{Pkh}+2 \mathrm{Gld}+11 \mathrm{H}_{2}
$$

where Po is Co-bearing pyrrhotite, $\left(\mathrm{Fe}_{10} \mathrm{Co}\right) \mathrm{S}_{12}, \mathrm{Py}$-pyrite, $\mathrm{Pkh}$-pakhomovskyite, Gld—gladiusite. Both phosphates form small (up to $0.5 \mathrm{~mm}$ in diameter) radiated aggregates of elongated plate crystals coloured dark brown (gladiusite) and bright pink (pakhomovskyite).
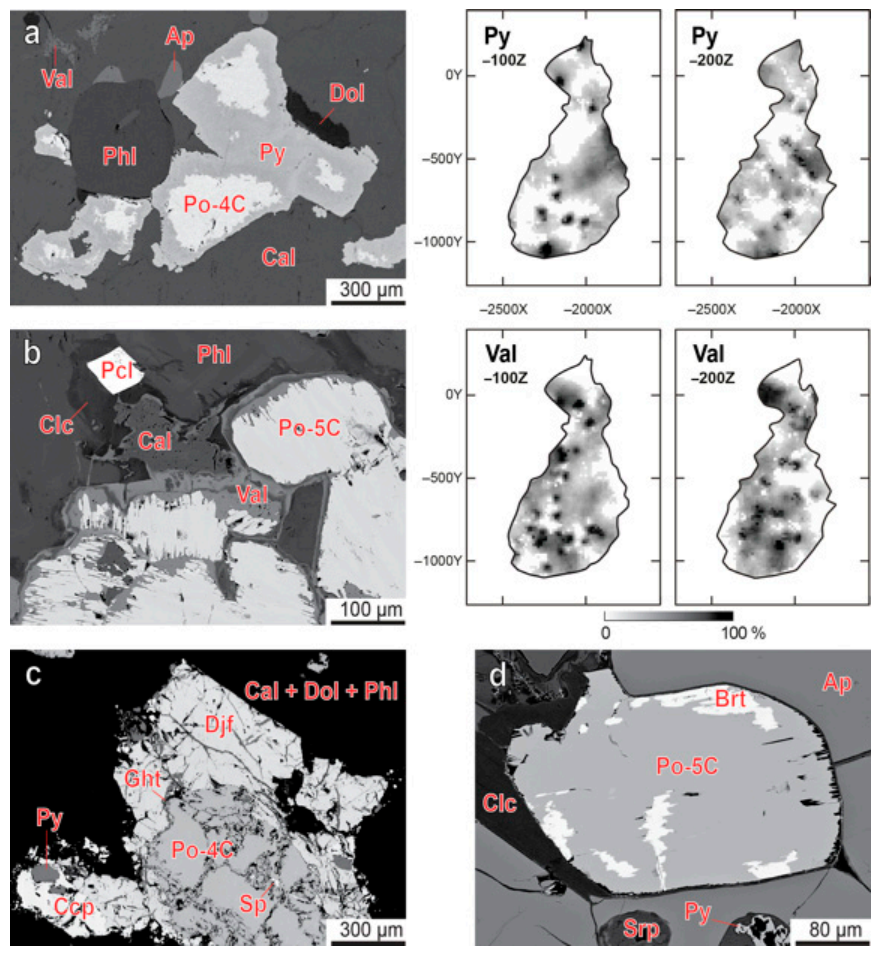

Figure 13. Replacement of pyrrhotite with pyrite ((a) phoscorite-related Cal-carbonatite 999/172.9), valleriite ((b) phoscorite-related Cal-carbonatite 972/86.9), djerfisherite ((c) phoscorite-related Cal-carbonatite 1004/656.5) and barite ((d) MAF-foscorite 941/41.5), BSE-images, and probability of apopyrrhotite pyrite and valleriite presence in the phoscorite-carbonatite complex. Mineral abbreviations are shown in Section 2.

\subsection{Chalcopyrite and Products of Its Alteration}

In natural sequence of the Kovdor rocks, content of copper gradually increases from host silicate rocks to earlier (apatite)-forsterite phoscorite, intermediate low-carbonate magnetite-rich phoscorite, and then to the latest calcite-rich phoscorite and carbonatites (see Table 2). On this reason, chalcopyrite content and grain size increase with growth of carbonate amount in the rock (up to 15 modal \% and $1 \mathrm{~cm}$ in diameter, Figure 14a). In fact, this mineral is absent in peridotite and, rarer, in non-altered foidolite. In hydrothermally altered ijolite-urtite, it occurs as inclusions (up to $40 \mu \mathrm{m}$ in diameter) in newly formed cancrinite (see Figure 2c) and calcite. Apo-peridotite diopsidite and phlogopitite contain irregularly shaped chalcopyrite grains (up to $1 \mathrm{~mm}$ in diameter) associated with pyrrhotite, magnetite and ilmenite in interstices of rock-forming silicates and apatite (see Figure 2d). 

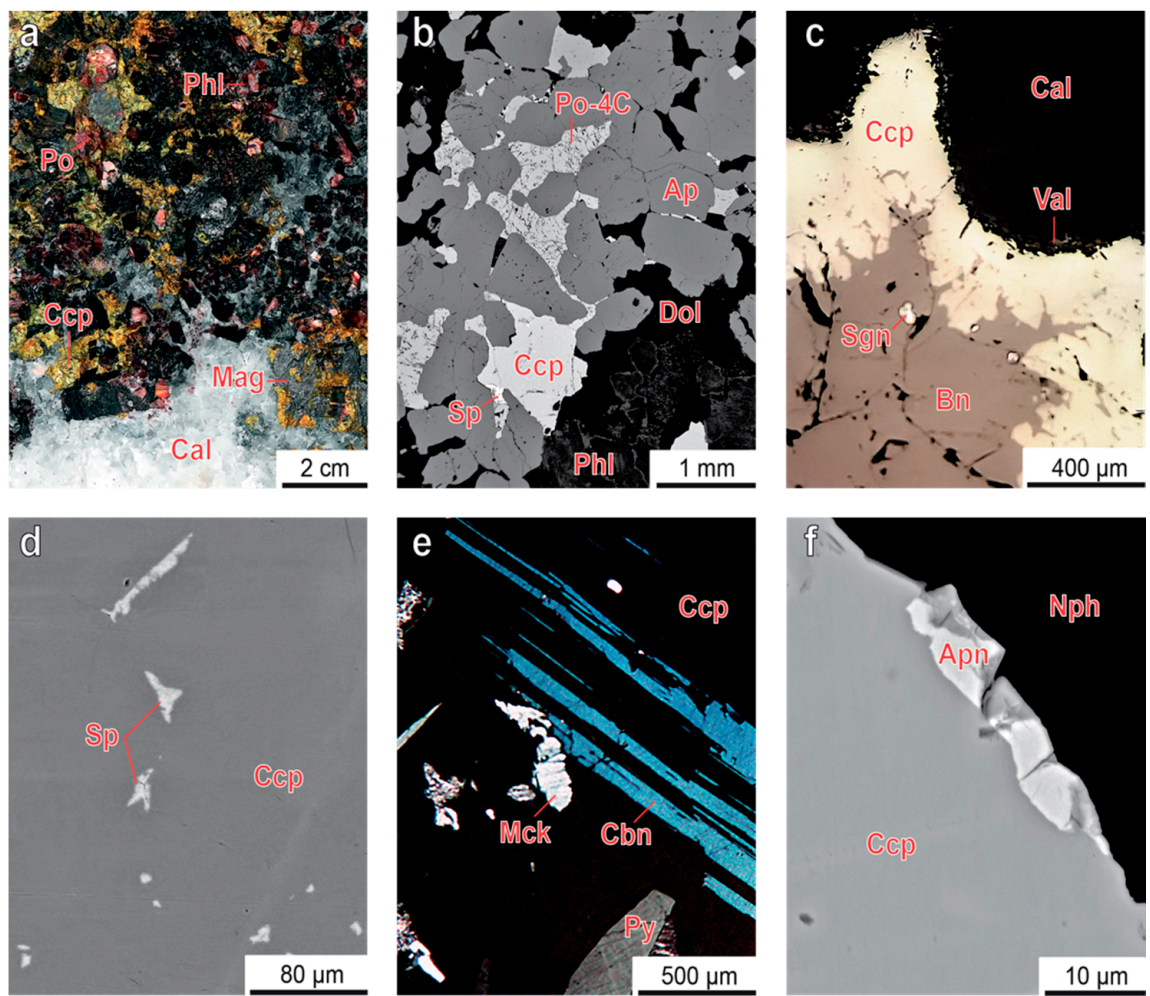

Figure 14. Chalcopyrite morphology and typical inclusions: (a) rich pyrrhotite-chalcopyrite mineralization in CMAF-phoscorite (K-2002, photo of hand specimen); (b) interstitial grains of sphalerite-containing chalcopyrite and pyrrhotite (MA-phoscorite 968/11.0, BSE-image); (c) bornite relict in chalcopyrite grain rimmed by valleriite (CMAF-phoscorite 2002/Bn2, photo in polarized reflected light); (d) exsolution inclusions of sphalerite in chalcopyrite (MA-phoscorite 968/11.0, BSE-image); (e) exsolution inclusions of cubanite in mackinawite-containing chalcopyrite (CMAF-phoscorite K-97-3, photo in polarized reflected light with crossed polarizers); (f) argentopentlandite inclusion in chalcopyrite (ijolite 949/209.2, BSE-image). Mineral abbreviations are shown in Section 2.

Marginal (apatite)-forsterite phoscorite is usually free from chalcopyrite. In intermediate low-carbonate phoscorite, chalcopyrite, together with pyrrhotite, fills interstices between grains of earlier forsterite, phlogopite, hydroxylapatite and magnetite (Figure 14b). Chalcopyrite usually occurs in marginal parts of pyrrhotite-chalcopyrite segregations or forms irregularly shaped gulf-like inclusions growing inside pyrrhotite grains from their margins. It also fills cleavage fractures in phlogopite, impregnates serpentine pseudomorphs after forsterite, accompanies late dolomite veinlets and segregations. In voids of vein dolomite carbonatite, late chalcopyrite forms druses of well-shaped tetrahedral crystals (up to $1 \mathrm{~mm}$ in diameter) in association with pyrite, anatase and titanite [11].

In calcite-rich phoscorite and carbonatite, chalcopyrite forms irregularly shaped chalcopyrite grains (up to $1 \mathrm{~cm}$ in diameter, see Figure 14a) partially replaced and rimmed by fine-grained pyrrhotite (see Figure 2h), as well as inclusions in magnetite, calcite and dolomite. Chalcopyrite grains sometimes contain irregularly shaped relicts (up to $15 \mu \mathrm{m}$ in diameter, Figure 14c) of high bornite (cubic, $a=5.47 \AA$ ) accompanied by newly formed covellite [11].

Chemical composition of chalcopyrite varies insignificantly (Table 10), and its averaged formula corresponds to a theoretical one. Nevertheless, like pyrrhotite, chalcopyrite contains different exsolution inclusions (Table 11); therefore, we can assume that its initial composition is more complex. In particular, chalcopyrite grains usually carry sharply bounded cross- or star-like exsolution inclusions of sphalerite (up to $100 \mu \mathrm{m}$ in diameter), as well as its gradually bounded rims around chalcopyrite grains and veinlets within them (up to $20 \mu \mathrm{m}$ thick, Figure 14d). In axial carbonate-rich phoscorite and phoscorite-related carbonatite, there are exsolution inclusions of cubanite in mackinawite-bearing chalcopyrite (Figure 14e). 
Cubanite forms brass-yellow, uniformly oriented, long prismatic inclusions (up to $3 \mathrm{~mm} \times 1.5 \mathrm{~mm}$ ) with split ends, as well as micro-granular aggregates, up to $1 \mathrm{~mm}$ in diameter $[11,14]$. Mackinawite occurs as wedge-shaped grains, skeletal crystals and stellate intergrowths (up to $100 \mu \mathrm{m}$ in diameter, see Figure 14e), which are abundant in chalcopyrite, but relict or even absent in co-existing cubanite [11].

Table 10. Chemical composition of chalcopyrite (mean $\pm \mathrm{SD} / \mathrm{min}-\mathrm{max}$ ).

\begin{tabular}{|c|c|c|c|c|c|}
\hline \multirow{2}{*}{ Rock } & \multicolumn{3}{|c|}{ Phoscorite and Related Carbonatite } & \multicolumn{2}{|c|}{ Vein Carbonatite } \\
\hline & (Ap)-Fo & Low-Cb Mag-Rich & Cal-Rich & Cal & Dol \\
\hline$n$ & 2 & 2 & 2 & 2 & 2 \\
\hline $\mathrm{S}, \mathrm{wt} \%$ & $\begin{array}{c}34.1 \pm 0.8 \\
33.53-34.70\end{array}$ & $\begin{array}{c}34.7 \pm 0.1 \\
34.60-34.79\end{array}$ & $\begin{array}{c}35.0 \pm 0.9 \\
34.40-35.68\end{array}$ & $\begin{array}{c}34.9 \pm 0.1 \\
34.86-35.00\end{array}$ & $\begin{array}{c}35.1 \pm 0.3 \\
34.83-35.29\end{array}$ \\
\hline $\mathrm{Fe}$ & $\begin{array}{c}30.6 \pm 0.2 \\
30.40-30.73\end{array}$ & $\begin{array}{c}29.9 \pm 0.2 \\
29.76-30.02\end{array}$ & $\begin{array}{c}30.4 \pm 0.3 \\
30.22-30.65\end{array}$ & $\begin{array}{c}30.1 \pm 0.5 \\
29.80-30.50\end{array}$ & $\begin{array}{c}30.8 \pm 0.1 \\
30.74-30.92\end{array}$ \\
\hline Co & $<0.01$ & $\begin{array}{l}0.01 \pm 0.01 \\
<0.01-0.02\end{array}$ & $\begin{array}{c}0.03 \pm 0.1 \\
0.02-0.04\end{array}$ & $<0.01$ & $<0.01$ \\
\hline $\mathrm{Ni}$ & $<0.01$ & $\begin{array}{l}0.02 \pm 0.02 \\
<0.01-0.04\end{array}$ & $\begin{array}{l}0.01 \pm 0.01 \\
<0.01-0.02\end{array}$ & $\begin{array}{l}0.01 \pm 0.02 \\
<0.01-0.02\end{array}$ & $\begin{array}{l}0.02 \pm 0.02 \\
<0.01-0.03\end{array}$ \\
\hline $\mathrm{Cu}$ & $\begin{array}{c}35.0 \pm 0.3 \\
34.80-35.29\end{array}$ & $\begin{array}{c}34.29 \pm 0.05 \\
34.26-34.32\end{array}$ & $\begin{array}{c}34.3 \pm 0.5 \\
33.93-34.58\end{array}$ & $\begin{array}{c}34.0 \pm 0.3 \\
33.80-34.24\end{array}$ & $\begin{array}{c}34.5 \pm 0.1 \\
34.39-34.53\end{array}$ \\
\hline $\mathrm{Zn}$ & $<0.01$ & $<0.01$ & $<0.01$ & $\begin{array}{l}0.3 \pm 0.3 \\
0.00-0.50\end{array}$ & $<0.01$ \\
\hline $\mathrm{Cu}, a p f u$ & $\begin{array}{c}1.04 \pm 0.04 \\
1.01-1.06\end{array}$ & 1.00 & $\begin{array}{c}0.99 \pm 0.04 \\
0.96-1.01\end{array}$ & $\begin{array}{c}0.99 \pm 0.01 \\
0.98-0.99\end{array}$ & $\begin{array}{c}0.99 \pm 0.01 \\
0.99-1.00\end{array}$ \\
\hline $\mathrm{Fe}$ & $\begin{array}{c}1.03 \pm 0.03 \\
1.01-1.05\end{array}$ & 0.99 & $\begin{array}{c}1.00 \pm 0.02 \\
0.99-1.01\end{array}$ & $\begin{array}{c}0.99 \pm 0.02 \\
0.98-1.00\end{array}$ & $\begin{array}{c}1.01 \pm 0.01 \\
1.00-1.01\end{array}$ \\
\hline$S$ & 2 & 2 & 2 & 2 & 2 \\
\hline
\end{tabular}

Table 11. Chemical composition of characteristic inclusions in chalcopyrite (wt \%/apfu).

\begin{tabular}{|c|c|c|c|c|c|}
\hline Mineral & Bn & Cbn & Mck & Sgn & $S p$ \\
\hline Sample & KZh-25b & $\mathrm{K}-97-3$ & K-97-3 & $2002 / B n 2$ & K-97-3 \\
\hline Rock & CM-phoscorite & CMF-phoscorite & CMF-phoscorite & CMAF-phoscorite & CMF-phoscorite \\
\hline S & $25.34 / 4.00$ & $35.57 / 3.00$ & $35.87 / 8.00$ & $41.90 / 4.00$ & $33.94 / 1.00$ \\
\hline Mn & bd & bd & bd & bd & $1.59 / 0.03$ \\
\hline $\mathrm{Fe}$ & $11.82 / 1.07$ & $41.09 / 1.99$ & $51.59 / 6.61$ & $0.57 / 0.03$ & $13.38 / 0.23$ \\
\hline Co & bd & bd & $12.50 / 1.52$ & $19.72 / 1.02$ & bd \\
\hline $\mathrm{Ni}$ & $\mathrm{bd}$ & $\mathrm{bd}$ & $0.40 / 0.05$ & $35.98 / 1.88$ & bd \\
\hline $\mathrm{Cu}$ & $62.67 / 4.99$ & $23.70 / 1.01$ & bd & $2.12 / 0.10$ & $0.71 / 0.01$ \\
\hline $\mathrm{Zn}$ & bd & bd & bd & bd & $46.17 / 0.67$ \\
\hline $\mathrm{Cd}$ & bd & bd & bd & bd & $4.80 / 0.04$ \\
\hline Total & $99.83 / 10.06$ & $100.36 / 6.00$ & $100.36 / 16.18$ & $100.29 / 7.03$ & $100.59 / 1.98$ \\
\hline Mineral & Hwl & Apn & Acn & Vol & Tsu \\
\hline Sample & $1009 / 121.4$ & $910 / 348.2$ & $999 / 76.6$ & $913 / 57.1$ & $913 / 57.1$ \\
\hline Rock & MF-phoscorite & Diopsidite & CMAF-phoscorite & CM-phoscorite & CM-phoscorite \\
\hline S & $23.76 / 1.00$ & $30.78 / 8.00$ & $12.45 / 1.00$ & bd & bd \\
\hline $\mathrm{Fe}$ & $3.12 / 0.08$ & $32.43 / 4.84$ & bd & $\mathrm{bd}$ & $3.58 / 0.11$ \\
\hline Co & bd & $0.34 / 0.05$ & bd & bd & bd \\
\hline $\mathrm{Ni}$ & bd & $23.08 / 3.28$ & $\mathrm{bd}$ & $\mathrm{bd}$ & $\mathrm{bd}$ \\
\hline $\mathrm{Cu}$ & $6.50 / 0.14$ & bd & $\mathrm{bd}$ & $\mathrm{bd}$ & $\mathrm{bd}$ \\
\hline $\mathrm{Zn}$ & $8.29 / 0.17$ & bd & $\mathrm{bd}$ & bd & $\mathrm{bd}$ \\
\hline $\mathrm{Ag}$ & bd & $13.35 / 1.03$ & $87.03 / 2.08$ & $19.82 / 1.08$ & $\mathrm{bd}$ \\
\hline $\mathrm{Cd}$ & $58.11 / 0.70$ & bd & bd & bd & bd \\
\hline $\mathrm{Te}$ & bd & $\mathrm{bd}$ & $\mathrm{bd}$ & $43.52 / 2.00$ & $38.07 / 1.00$ \\
\hline $\mathrm{Bi}$ & bd & bd & bd & $35.79 / 1.00$ & $58.42 / 0.94$ \\
\hline Total & $99.78 / 2.09$ & $99.98 / 17.20$ & $99.48 / 3.08$ & $99.13 / 4.08$ & $100.07 / 2.05$ \\
\hline
\end{tabular}

In addition to the minerals described above, $<50 \mu \mathrm{m}$ sized inclusions of galena, hawleyite, argentopentlandite, siegenite and acanthite were found in chalcopyrite grains [11]. Galena and 
hawleyite form rounded grains at the contacts between chalcopyrite and pyrrhotite, bornite, covellite, carbonates. Argentopentlandite (Figure 14f) occurs in ijolite, diopsidite and phlogopitite as irregularly shaped inclusions (up to $30 \mu \mathrm{m}$ ) in marginal parts of chalcopyrite grains. Siegenite together with galena, hawleyite, wittichenite and covellite form small $(10-70 \mu \mathrm{m})$ inclusions in bornite and chalcopyrite pseudomorphs after bornite (see Figure 14c). Irregularly shaped grains of acanthite (up to $20 \mu \mathrm{m}$ ) were found at the contact between pyritized chalcopyrite and calcite.

Besides, chalcopyrite may contain fine impregnation of volynskite, tsumoite and native silver. Volynskite and tsumoite were found in calcite-magnetite phoscorite as thin intergrowth (up to $5 \mu \mathrm{m}$ in diameter) within chalcopyrite inclusions in magnetite. Native silver forms thin $(<1 \mu \mathrm{m}$ thick) veinlets and xenomorphic inclusions (up to $3 \mu \mathrm{m}$ in diameter) in chalcopyrite grains, especially, at the contacts between chalcopyrite grains and pyrrhotite, sphalerite.

Typical products of chalcopyrite alteration include valleriite, djerfisherite, chalcocite, covellite, pyrite and goethite (Table 12), which replace chalcopyrite grains from margins and fractures (see Figure 14c), up to formation of complete pseudomorphs after chalcopyrite:

$$
\begin{gathered}
16 \mathrm{Ccp}+2 \mathrm{H}_{2} \mathrm{O}+3 \mathrm{O}_{2}=12 \mathrm{Py}+8 \mathrm{Cct}+4 \mathrm{Gth}, \\
2 \mathrm{Ccp}+3 \mathrm{Mgs}+3 \mathrm{H}_{2} \mathrm{O}=\mathrm{Val}+\mathrm{CO}_{2}, \\
25 \mathrm{Ccp}+12 \mathrm{KCl}+2 \mathrm{NaCl}+2 \mathrm{~S}+\mathrm{Cl}_{2}=2 \mathrm{Djf}, \text { etc. }
\end{gathered}
$$

where $\mathrm{Ccp}$ is chalcopyrite, $\mathrm{FeCuS}_{2}$; $\mathrm{Cct}$-chalcocite, $\mathrm{Cu}_{2} \mathrm{~S}$; Djf-djerfisherite, $\mathrm{K}_{6} \mathrm{NaFe}_{12.5} \mathrm{Cu}_{12.5} \mathrm{~S}_{26} \mathrm{Cl}$; Gth-goethite, $\mathrm{FeO}(\mathrm{OH})$; Mgs-magnesite, $\mathrm{MgCO}_{3} ; \mathrm{Py}$-pyrite, $\mathrm{FeS}_{2}$ and Val-valleriite, $\mathrm{Mg}_{3} \mathrm{Fe}_{2} \mathrm{Cu}_{2} \mathrm{~S}_{4}(\mathrm{OH})_{6}$.

Table 12. Chemical composition of characteristic products of chalcopyrite alteration (wt \%/apfu).

\begin{tabular}{cccccc}
\hline Mineral & Val & Djf & Cct & Cv & Py \\
\hline Sample & KZh-25b & K-97-3 & K-01-1110 & K-02-122 & K-0042 \\
Rock & CM-phoscorite & CMF-phoscorite & CMAF-phoscorite & CM-phoscorite & Dol-carbonatite \\
Mg & $11.12 / 2.54$ & bd & bd & bd & bd \\
$\mathrm{Al}$ & $3.57 / 0.73$ & $\mathrm{bd}$ & $\mathrm{bd}$ & $\mathrm{bd}$ & $\mathrm{bd}$ \\
$\mathrm{S}$ & $23.14 / 4.00$ & $32.91 / 26.00$ & $19.64 / 1.00$ & $31.68 / 1.00$ & $53.20 / 2.00$ \\
$\mathrm{Cl}$ & $\mathrm{bd}$ & $0.63 / 0.45$ & $\mathrm{bd}$ & $\mathrm{bd}$ & $\mathrm{bd}$ \\
$\mathrm{K}$ & $\mathrm{bd}$ & $9.06 / 5.87$ & $\mathrm{bd}$ & $\mathrm{bd}$ & $\mathrm{bd}$ \\
$\mathrm{Fe}$ & $25.66 / 2.55$ & $35.55 / 16.13$ & $\mathrm{bd}$ & $1.54 / 0.03$ & $46.76 / 1.01$ \\
$\mathrm{Co}$ & $\mathrm{bd}$ & $0.06 / 0.03$ & $\mathrm{bd}$ & $\mathrm{bd}$ & $0.36 / 0.01$ \\
$\mathrm{Ni}$ & $0.12 / 0.01$ & $1.40 / 0.60$ & $\mathrm{bd}$ & $\mathrm{bd}$ & $0.02 / 0.00$ \\
$\mathrm{Cu}$ & $12.06 / 1.05$ & $16.51 / 6.58$ & $79.12 / 2.03$ & $66.30 / 1.06$ & $\mathrm{bd}$ \\
$\mathrm{Ag}$ & $\mathrm{bd}$ & $3.34 / 0.78$ & $\mathrm{bd}$ & $\mathrm{bd}$ & $\mathrm{bd}$ \\
Total & $75.67 / 10.88$ & $99.46 / 56.44$ & $98.76 / 3.03$ & $99.52 / 2.09$ & $100.34 / 3.02$ \\
\hline
\end{tabular}

Different low-temperature copper minerals appear also in neighboring voids and fractures. In particular, several funnels of staffelite breccia in apical (now excavated) part of the phoscorite-carbonatite pipe axial zone are formed by fragments of altered chalcopyrite-rich phoscorite and carbonatite cemented by bluish green colloform fluorapatite with inclusions of brochantite, $\mathrm{Cu}_{4}\left[\mathrm{SO}_{4}\right](\mathrm{OH})_{6}$, malachite, $\left(\mathrm{Cu}_{1.98} \mathrm{Fe}_{0.02}\right)_{2.00}\left[\mathrm{CO}_{3}\right](\mathrm{OH})_{2}$, pseudomalachite, $\left(\mathrm{Cu}_{4.85} \mathrm{Ca}_{0.07}\right)_{4.92}\left[\mathrm{P}_{2.03} \mathrm{O}_{8}\right](\mathrm{OH})_{4}$, chrisocolla, $\left(\mathrm{Cu}_{1.85} \mathrm{Ca}_{0.03}\right)_{1.88} \mathrm{H}_{2.00} \mathrm{Si}_{2.06} \mathrm{O}_{5}(\mathrm{OH})_{4} \cdot n \mathrm{H}_{2} \mathrm{O}$, tenorite, $\mathrm{Cu}_{1.00} \mathrm{O}$, and goethite $\left(\mathrm{Fe}_{0.86} \mathrm{Si}_{0.11}\right)_{0.97} \mathrm{O}(\mathrm{OH})$ [11].

\section{Discussion}

The Kovdor phoscorite-carbonatite complex has gradual concentric zonation in terms of the rocks modal and chemical composition, as well as grain size, chemical composition, crystallochemical features and properties of rock-forming and accessory minerals [11,21,22,24,26-29]. This zonation 
mainly results from gradual change in chemical composition of the residual phoscorite melt from silicate-rich to carbonate-rich during crystallization from the pipe margins to its axial zone [22].

Geochemically, nickel behaves like $\mathrm{Mg}$ and $\mathrm{Fe}^{2+}$, and readily substitutes them in most crystalline phases including olivine [71]. Besides, there is a strong negative dependence of $\mathrm{Ni}$ activity on $\mathrm{FeO}_{\text {tot }}$ content in silicate melt [72,73]. However, even in a high-magnesian system, like the Kovdor peridotite and forsteritite, nickel can remain in the residual silicate melt (SM) because its partition coefficient $D^{\mathrm{Ol} / \mathrm{SM}}$ depends significantly on sulfur content [74]. In fact, at fixed $P-T$ conditions, the partition coefficients of chalcophile elements $M$ between monosulfide solid solution (MSS), ( $\mathrm{Fe}, \mathrm{Ni}, \mathrm{Co})_{1-x} \mathrm{~S}$, and silicate melt are controlled by the ratio $\mathrm{fS}_{2} / f_{2}$, which, in turn, depends on $\mathrm{FeO}_{\text {tot }}$ content in sulfide-saturated silicate melt [75-77]:

$$
\begin{gathered}
(\mathrm{Fe}, M) \mathrm{O}_{(\mathrm{SM})}+0.5 \mathrm{~S}_{2}=(\mathrm{Fe}, M) \mathrm{S}_{(\mathrm{MSS})}+0.5 \mathrm{O}_{2} \\
\mathrm{MO}_{(\mathrm{SM})}+\mathrm{FeS}_{(\mathrm{MMS})}=\mathrm{MS}_{(\mathrm{MSS})}+\mathrm{FeO}_{(\mathrm{SM})} .
\end{gathered}
$$

As a result, the MSS-SM partition coefficients for Ni, $\mathrm{Cu}$ and Co substantially increase with $\mathrm{FeO}_{\text {tot }}$ decrease in silicate melt (Figure 15a), and we can conclude that crystallization of Mg-rich (apatite)-forsterite phoscorite can produce $\mathrm{Fe}-\mathrm{Ni}$-Co-Cu-rich sulfide melt.
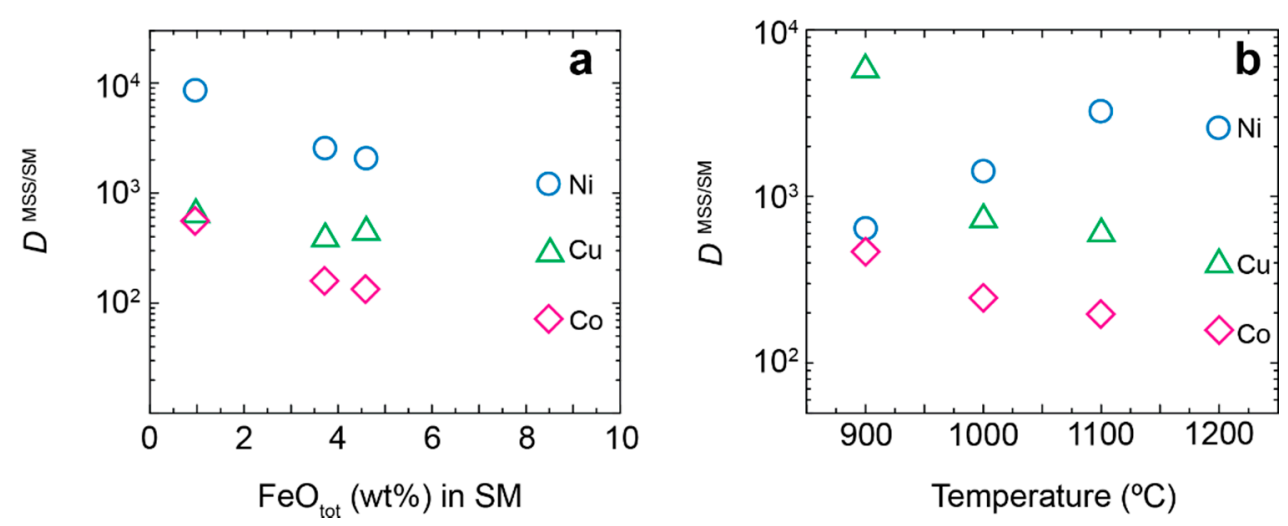

Figure 15. Effect of $\mathrm{FeO}_{\text {tot }}$ content in $\mathrm{SM}\left((\mathbf{a}) \mathrm{T}=1200{ }^{\circ} \mathrm{C}\right.$ and $\left.P=1.5 \mathrm{GPa}\right)$ and melt temperature ((b) $\left.\mathrm{FeO}_{\text {tot }}=3.7 \mathrm{wt} \%\right)$ on partition coefficients of Ni, Co and $\mathrm{Cu}$ between MSS and SM [77].

In earlier low-carbonate phoscorite, pyrrhotite is formed at the final stage of magnetite crystallization, because comparatively low sulfur content (see Table 2) still requires melt saturation in FeS complexes. For this reason, ferrimagnetic pyrrhotite-4C (or the corresponding MSS) first closely associates with magnetite forming gulf-like ingrowths inside its grains. Then, with transition to carbonate-rich phoscorite and carbonatite, iron-rich pyrrhotite-5-6C (or the corresponding MSS) crystallizes independently of magnetite. Increase of mean equivalent circular diameter of pyrrhotite grains reflects a decrease of the rock crystallization rate from the pipe wall to its axis. This trend is similar to that of co-existing rock-forming and accessory minerals, in particular, forsterite, magnetite and baddeleyite $[22,26,27]$.

Our data on crystal structure of the Kovdor pyrrhotites are consistent with numerous previous studies of the structure $[48,51,54-57,78]$, which demonstrate different space groups for the most common $4 \mathrm{C}, 5 \mathrm{C}$ and $6 \mathrm{C}$ polytypes. Such structural diversity is caused by different $P-T$ conditions of crystallization, amount of incorporated $\mathrm{Fe}^{3+}$ or different mechanisms of vacancies distribution in the structure. According to the structural complexity classification $[79,80], 4 \mathrm{C}$ polytype is "simple", while 5C and 6C modifications are "intermediate" (Figure 16). Relatively low-temperature formation of pyrrhotite-5C in comparison with pyrrhotite- $4 \mathrm{C}$ is in good agreement with a common tendency of structural complexity growth with crystallization temperature decrease. From this point of view, use of 
the term 'pyrrhotite- $n C$ ' for $5 C$ and $6 C$ polytypes is justified by the absence of significant differences between their complexity.

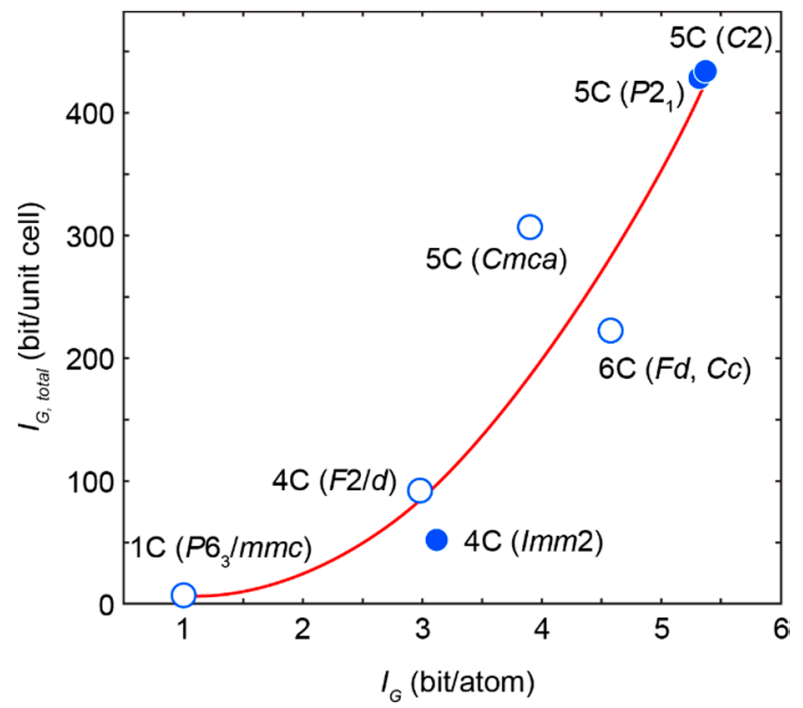

Figure 16. Total structural information content of pyrrhotite $\left(I_{G, \text { total }}\right)$ plotted against the information content per atom $\left(I_{G}\right)$ according to $[48,50,51,54,57]$ (empty circles) and our data (full circles).

Decrease of monosulfide crystallization temperature causes growth of $D^{\mathrm{MSS} / \mathrm{SM}}$ for $\mathrm{Cu}$ and Co (Figure 15b), while Ni partition coefficient remains the same or even decreases [77,81], which enables fractionation of $\mathrm{Ni}$ and $\mathrm{Cu}$-Co between low- and high-temperature sulfides respectively. Therefore, we believe that concentrically zoned distribution of pyrrhotite with different $\mathrm{Fe}, \mathrm{Ni}$ and Co contents is a response to a gradual decrease of crystallization temperature from the ore-pipe marginal forsterite-dominant zone to its axial carbonate-rich zone. Exsolution of MSS or the corresponding higher-temperature pyrrhotite modifications produced lamella or flames of pentlandite in the ore-pipe marginal zone, and cobaltpentlandite in the pipe axial zone.

For the same reason, copper is concentrated in the pipe axial carbonate-rich zone. Carbonate melt appears to contain a significant amount of water [82] and copper as stable hydrosulfide complexes [83]. Their destruction by bornite and chalcopyrite crystallization after carbonates caused intensive hydrothermal alteration of associated minerals, and formation of secondary pyrite, valleriite and other phases.

It is interesting to compare sulfide mineralization of the phoscorite-carbonatite complexes of the Kovdor (Russia) and Palabora (South Africa) alkaline-ultrabasic massifs that have comparable composition, structure and metallogenic specialization [12]. However, the Loolekop phoscorite-carbonatite pipe in the Palabora massif is the largest carbonatite-hosted copper deposit in the world $850 \mathrm{Mt} @ 0.5 \% \mathrm{Cu}$ [84], and the Kovdor phoscorite-carbonatite complex has comparatively low copper content. What caused such a significant enrichment of the Loolekop phoscorite and carbonatites in copper?

The Loolekop phoscorite-carbonatite pipe is a close relative to the Kovdor one. The Loolekop pipe $(1.4 \mathrm{~km} \times 0.8 \mathrm{~km})$ is situated in the eastern part of the Proterozoic central-type Palabora complex of apo-peridotite serpentinite (central stock), shonkinite (outer ring intrusion) and the related diopsidite and phlogopitite between them. It has a clear concentric zonation with marginal low-carbonate phoscorite, intermediate "banded" zone of interlayered carbonate-rich phoscorite and phoscorite-related calcite carbonatite and axial stockwork of "transgressive" calcite and dolomite carbonatite [85-87].

All these rocks are rich in pyrrhotite with exsolution inclusions of pentlanditecobaltpentlandite [87], and contain also sufficient amount of copper sulfides: dominant bornite and 
chalcocite in phoscorite and banded carbonatite and dominant chalcopyrite with relicts of bornite and exsolution inclusions of cubanite in transgressive carbonatite $[85,86,88,89]$. Minor copper minerals include covellite, valleriite, tetrahedrite, and native copper $[12,85,90]$. As a result, copper content increases from $<0.3 \mathrm{wt} \%$ in marginal phoscorite to $0.3-0.9 \mathrm{wt} \%$ in intermediate banded carbonatite and about $1 \mathrm{wt} \%$ in axial transgressive carbonatite $[85,86]$.

In phoscorite and phoscorite-related "banded" carbonatite, sulfides fill interstices and thin fractures in magnetite-apatite-forsterite-calcite aggregate, and form irregularly shaped segregations with pyrrhotite in core and copper-bearing sulfides in marginal zone, while in the late "transgressive" carbonatite, they form subparallel vertical lenses and veinlets (usually, up to $3 \mathrm{~cm}$ thick) within a vertical ore-zone with cross-section about $200 \mathrm{~m} \times 600 \mathrm{~m}[85,87]$. In both rocks, pyrrhotite and pentlandite-cobaltpentlandite are the earliest sulfides, high bornite is the next one, and chalcopyrite and other minerals follow them.

Thus, the Kovdor and Loolekop phoscorite-carbonatite pipes have similar sequences of sulfide formation (Figure 17a), from earlier pyrrhotite to intermediate copper sulfides and late pyrite and valleriite. There are only differences in positions of argentopentlandite and mackinawite that are common products of chalcopyrite exsolution in the Kovdor complex, and substitute pentlandite in the Loolekop pipe $[12,87,89]$. It is necessary to note that secondary djerfisherite is widely spread in the Kovdor complex due to higher alkalinity of this massif.
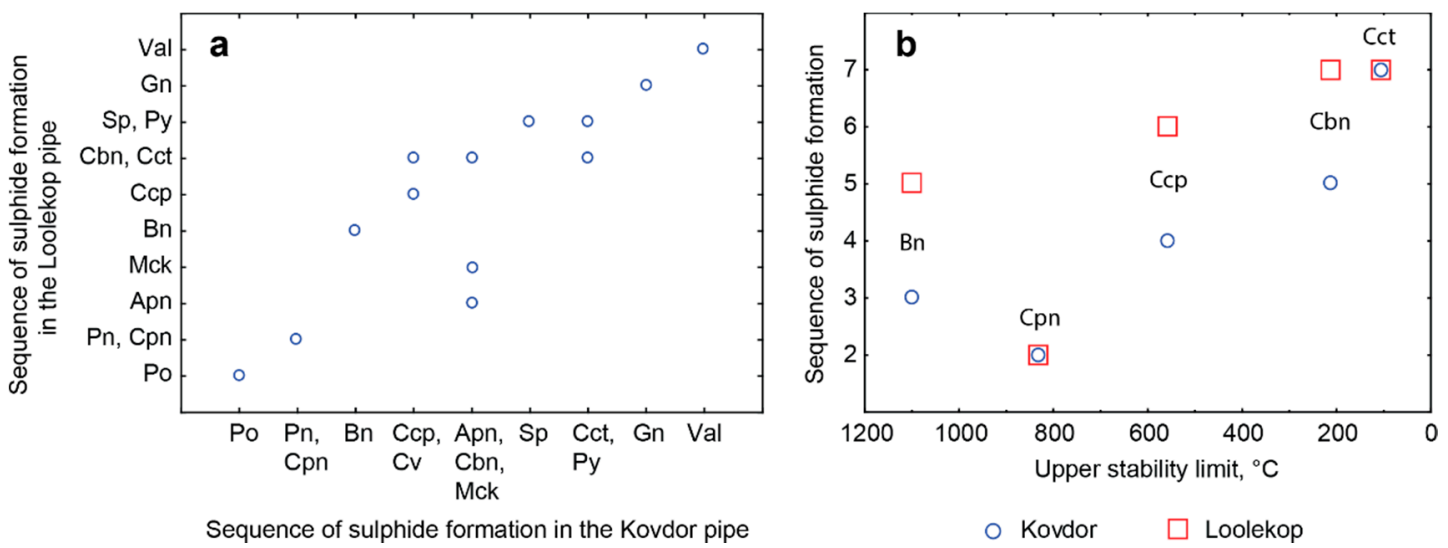

Figure 17. Order of sulfide formation in the Kovdor and Loolekop phoscorite-carbonatite pipes (a) and the corresponding stability temperature [62] for the Kovdor's sequence (b). Mineral abbreviations are shown in Section 2.

The sequences of sulfide formation in the phoscorite-carbonatite pipes are in a good accordance with the upper limits of their stability [62] that linearly decrease from $1100{ }^{\circ} \mathrm{C}$ for high bornite to $103{ }^{\circ} \mathrm{C}$ for chalcocite (Figure 17b). For the Kovdor complex, these relations can be supplemented with temperature of pyrite-pyrrhotite equilibration ranged from $170{ }^{\circ} \mathrm{C}$ in intermediate low-carbonate magnetite-rich phoscorite and dolomite carbonatite to $300^{\circ} \mathrm{C}$ in axial carbonate-rich phoscorite and phoscorite-related carbonatite, and temperatures of the pyrrhotite superstructure formation from $140{ }^{\circ} \mathrm{C}$ for pyrrhotite- $4 \mathrm{C}$ to $60{ }^{\circ} \mathrm{C}$ for pyrrhotite-5C [62].

One of the most likely reasons for sulfide specialization in the Loolekop phoscorite-carbonatite pipe in comparison with the Kovdor one is insignificant differences in oxygen fugacity of initial phoscorite melts (due to higher water content), because the larger oxygen fugacity causes more intensive copper extraction by melt from surrounding rocks [5,91-93]. In fact, even a slight increase in oxidation state (to $\geq \mathrm{FMQ}+1$ ) can shift the balance between sulfide and sulfate components dissolved in melt towards more soluble sulfates, allowing magmas to dissolve much larger amounts of sulfur than reduced melts [94]. Higher water content in the Palabora's magma is confirmed, in particular, 
by much deeper alteration of peridotite and phoscorite into serpentinite, much abundant pegmatites, much richer valleriite mineralization, etc. [85,90,95].

\section{Conclusions}

1. Primary silicate rocks of the Kovdor massif (peridotite, foidolite-melilitolite and forsteritite) are free of sulfides due to sulfur fractionation in fluid phase. For the same reason, hydrothermally altered parts of these rocks, including diopsidite, phlogopitite and skarn-like rocks, carry rich sulfide mineralization associated with secondary minerals (cancrinite, natrolite, phlogopite, clinochlore, serpentine, vesuvianite, etc.).

2. Distribution of rock-forming sulfides within the Kovdor phoscorite-carbonatite complex reflects gradual concentric zonation of the pipe: pyrrhotite with exsolution inclusions of pentlandite in marginal (apatite)-forsterite phoscorite, pyrrhotite with exsolution inclusions of cobaltpentlandite in intermediate low-carbonate magnetite-rich phoscorite, and chalcopyrite ( \pm pentlandite with exsolution inclusions of cobaltpentlandite) in axial carbonate-rich phoscorite and phoscorite-related carbonatite;

3. Both pyrrhotite and chalcopyrite fill interstices between the main rock-forming minerals, including carbonates, and form late veinlets and irregularly shaped segregations with inclusions of surrounding minerals. Usually, chalcopyrite (with relicts of earlier bornite and exsolution inclusions of cubanite and mackinawite) crystallizes around grains of pyrrhotite (with inclusions of pentlandite-cobaltpentlandite and pyrite), and both these minerals contain common exsolution inclusions of sphalerite. Temperature of pyrite-pyrrhotite equilibration ranges from $100{ }^{\circ} \mathrm{C}$ to $400{ }^{\circ} \mathrm{C}$, and pressure of pyrrhotite-sphalerite equilibration reaches $10 \mathrm{kbar}$;

4. For the most part, pyrrhotite corresponds to its non-magnetic $5 \mathrm{C}$ polytype. Ferrimagnetic pyrrhotite- $4 \mathrm{C}$ forms individual grains, marginal zones of non-magnetic pyrrhotite crystals and thin lens-like inclusions in pyrrhotite-5C. Low-temperature pyrrhotite $2 \mathrm{C}$ (troilite) occurs as lens-like exsolution inclusions in grains of pyrrhotite-4C and -5C. In natural sequence of the Kovdor rocks, iron content in pyrrhotite gradually increases from $\mathrm{Fe}_{7} \mathrm{~S}_{8}$ to $\mathrm{Fe}_{9} \mathrm{~S}_{10}$ and $\mathrm{Fe}_{11} \mathrm{~S}_{12}$ in accordance with gradual decrease of crystallization temperature and oxygen fugacity.

5. High complexity of crystal structure of pyrrhotite- $5 \mathrm{C}\left(I_{G, \text { total }}=429.75\right.$ bits per unit cell), which is the most common within the Kovdor massif, confirms the lowest temperature of its formation in comparison with other polytypes. Wide dissemination of this modification is associated with structural stability (variations in composition $\mathrm{Fe}_{8.84-8.99} \mathrm{~S}_{10}$ ) due to different vacancies ordering mechanisms resulting in two structural modifications: $P 2_{1}$ and $C 2$.

6. Within the phoscorite-carbonatite complex, content of Co in pyrrhotite gradually increases from host silicate rocks and marginal forsterite-dominant phoscorite to axial carbonate-rich phoscorite and carbonatite due to $\mathrm{Ni}$ and Fe. This dependence probably reflects a gradual decrease of crystallyzation temperature in primary monosulfide solid solutions from the pipe margin toward its axis.

7. Low-temperature hydrothermal alteration of pyrrhotite and chalcopyrite first produces partial or complete pseudomorphs of djerfisherite, pyrite, chalcocite, valleriite and goethite after the rock-forming sulfides, and then numerous phosphates and carbonates of $\mathrm{Fe}, \mathrm{Co}$ and $\mathrm{Cu}$ (baricite, gladiusite, malachite, mitridatite, pakhomovskyite, pseudomalachite, pyroaurite, siderite, strengite, vivianite) in surrounding voids and fissures.

8. The Kovdor and Loolekop phoscorite-carbonatite pipes have similar sequences of sulfide formation: pyrrhotite-pentlandite-cobaltpentlandite-bornite-chalcopyrite-covellite-cubanitesphalerite-pyrite-chalcocite-galena-vallereite. This sequence corresponds to the sulfide stability limits ranged from $1100{ }^{\circ} \mathrm{C}$ (high bornite) to $103^{\circ} \mathrm{C}$ (chalcocite) and even lower (for valleriite). Thus, copper specialization of the Loolekop pipe is not caused by any specific process but reflects stochastic specifics of the phoscorite-carbonatite genesis. 
9. Sulfide specialization of the Palabora massif can be caused by higher water content in its initial melt allowing it to dissolve much larger amounts of sulfur and, consequently, concentrate more chalcophile metals.

Supplementary Materials: The following are available online at http:/ /www.mdpi.com/2075-163X/8/7/292/s1, Table S1: Grain size and chemical composition of the pyrrhotite group minerals. The CIF files for structurally studied pyrrhotites $1-5$.

Author Contributions: G.Y.I. designed the experiments, performed statistical investigations and crystal size distribution analyses, and wrote the manuscript. T.L.P. carried out X-ray investigations. A.O.K. and P.M.G. performed geostatistical investigation, drew maps, took samples and reviewed the manuscript. Y.A.P. and A.V.B. took BSE images and performed electron microscope investigations. J.A.M. carried out petrographical investigations and reviewed the manuscript. V.N.Y. and N.G.K. conceived of the work, took and prepared samples. All authors discussed the manuscript.

Funding: The research is supported by the Russian Science Foundation, grant 16-17-10173.

Acknowledgments: Samples were taken during exploration of deep levels of the Kovdor deposit implemented by JSC Kovdorskiy GOK in 2007-2011. X-ray crystal studies were carried out with the equipment provided by the X-ray Diffraction Centre of Saint-Petersburg State University. The authors would like to thank I.R. Elizarova who performed the ICP-MS analyses of bulk-rock samples. Comments and remarks of anonymous reviewers were very useful.

Conflicts of Interest: The authors declare no conflict of interest. The founding sponsors had no role in the design of the study; in the collection, analyses or interpretation of data; in the writing of the manuscript; nor in the decision to publish the results.

\section{References}

1. Bailey, D.K.; Hampton, C.M. Volatiles in alkaline magmatism. Lithos 1990, 26, 157-165. [CrossRef]

2. Samson, I.M.; Williams-Jones, A.E.; Liu, W. The chemistry of hydrothermal fluids in carbonatites: Evidence from leachate and SEM-decrepitate analysis of fluid inclusions from Oka, Quebec, Canada. Geochim. Cosmochim. Acta 1995, 59, 1979-1989. [CrossRef]

3. Brooker, R.A.; Sparks, R.S.J.; Kavanagh, J.L.; Field, M. The volatile content of hypabyssal kimberlite magmas: Some constraints from experiments on natural rock compositions. Bull. Volcanol. 2011, 73, 959-981. [CrossRef]

4. Klimm, K.; Kohn, S.C.; Botcharnikov, R.E. The dissolution mechanism of sulphur in hydrous silicate melts. II: Solubility and speciation of sulphur in hydrous silicate melts as a function of $f \mathrm{O}_{2}$. Chem. Geol. 2012, 322-323, 250-267. [CrossRef]

5. Klimm, K.; Kohn, S.C.; Dell, L.A.O.; Botcharnikov, R.E.; Smith, M.E. The dissolution mechanism of sulphur in hydrous silicate melts. I: Assessment of analytical techniques in determining the sulphur speciation in iron-free to iron-poor glasses. Chem. Geol. 2012, 322-323, 237-249. [CrossRef]

6. Métrich, N.; Berry, A.J.; O'Neill, H.S.C.; Susini, J. The oxidation state of sulfur in synthetic and natural glasses determined by X-ray absorption spectroscopy. Geochim. Cosmochim. Acta 2009, 73, 2382-2399. [CrossRef]

7. O'Neill, H.S.C.; Mavrogenes, J.A. The Sulfide Capacity and the Sulfur Content at Sulfide Saturation of Silicate Melts at 1400 degrees C and 1 bar. J. Petrol. 2002, 43, 1049-1087. [CrossRef]

8. Klimm, K.; Botcharnikov, R.E. The determination of sulfate and sulfide species in hydrous silicate glasses using Raman spectroscopy. Am. Mineral. 2010, 95, 1574-1579. [CrossRef]

9. Seward, T.M.; Williams-Jones, A.E.; Migdisov, A.A. The Chemistry of Metal Transport and Deposition by Ore-Forming Hydrothermal Fluids. In Treatise on Geochemistry; Elsevier: Berlin, Germany, 2014; pp. 29-57. ISBN 9780080959757.

10. Reed, M.H.; Palandri, J. Sulfide Mineral Precipitation from Hydrothermal Fluids. Rev. Mineral. Geochem. 2006, 61, 609-631. [CrossRef]

11. Ivanyuk, G.Y.; Yakovenchuk, V.N.; Pakhomovsky, Y.A. Kovdor; Laplandia Minerals: Apatity, Russia, 2002; ISBN 5900395413.

12. Rudashevsky, N.S.; Kretser, Y.L.; Rudashevsky, V.N.; Sukharzhevskaya, E.S. A review and comparison of PGE, noble-metal and sulphide mineralization in phoscorites and carbonatites from Kovdor and Phalaborwa. In Phoscorites and Carbonatites from Mantle to Mine: The Key Example of the Kola Alkaline Province; Wall, F., Zaitsev, A.N., Eds.; Mineralogical Society: London, UK, 2004; pp. 375-405. 
13. Kukharenko, A.A.; Orlova, M.P.; Bulakh, A.G.; Bagdasarov, E.A.; Rimskaya-Korsakova, O.M.; Nefedov, E.I.; Ilyinsky, G.A.; Sergeev, A.S.; Abakumova, N.B. Caledonian Complex of Ultrabasic, Alkaline Rocks and Carbonatites of Kola Peninsula and Northern Karelia (Geology, Petrology, Mineralogy and Geochemistry); Nedra: Moscow, Russia, 1965. (In Russian)

14. Bykova, E. Sulphide mineralization in magnetite ores and carbonatites of the Kovdor massif. Mineral. Geochem. 1975, 5, 11-16. (In Russian)

15. Subbotina, G.F.; Subbotin, V.V.; Pakhomovsky, Y.A. Some features of a sulphide mineralization of apatite-magnetite ores and carbonatites of the Kovdor deposit. In Substantial Composition of Alkaline Intrusive Complexes of the Kola Peninsula; KFAN USSR: Apatity, Russia, 1981; pp. 88-95.

16. Balabonin, N.L.; Voloshin, A.V.; Pakhomovsky, Y.A. Rare sulphides in rocks of the Kovdor deposit. In Mineral Complexes and Minerals of the Kola Peninsula; KFAN USSR: Apatity, Russia, 1980; pp. 88-92. (In Russian)

17. Balabonin, N.L.; Voloshin, A.V.; Pakhomovsky, Y.A.; Polyakov, K.I. Composition of djerfisherite from alkaline complexes of the Kola Peninsula. Mineral. Zhurnal 1980, 1, 90-99. (In Russian)

18. Kapustin, Y.L. Mineralogy of Carbonatites; Amerind Publishing: New Delhi, India, 1980.

19. Rimskaya-Korsakova, O.M.; Krasnova, N.I. Geology of Deposits of the Kovdor Massif; St. Petersburg University Press: St. Petersburg, Russia, 2002. (In Russian)

20. Krasnova, N.I.; Petrov, T.G.; Balaganskaya, E.G.; García, D.; Moutte, J.; Zaitsev, A.N.; Wall, F. Introduction to phoscorites: Occurrence, composition, nomenclature and petrogenesis. In Phoscorites and Carbonatites from Mantle to Mine: The Key Example of the Kola Alkaline Province; Zaitsev, A.N., Wall, F., Eds.; Mineralogical Society: London, UK, 2004; pp. 43-72, ISBN 0903056224.

21. Afanasyev, B.V. Mineral Resources of Alkaline-Ultrabasic Massifs of the Kola Peninsula; Roza Vetrov Publishing: St. Petersburg, Russia, 2011. (In Russian)

22. Mikhailova, J.A.; Ivanyuk, G.Y.; Kalashnikov, A.O.; Pakhomovsky, Y.A.; Bazai, A.V.; Panikorovskii, T.L.; Yakovenchuk, V.N.; Konopleva, N.G.; Goryainov, P.M. Three-D Mineralogical Mapping of the Kovdor Phoscorite-Carbonatite Complex, NW Russia: I. Forsterite. Minerals 2018, 8, 260. [CrossRef]

23. Mikhailova, J.A.; Kalashnikov, A.O.; Sokharev, V.A.; Pakhomovsky, Y.A.; Konopleva, N.G.; Yakovenchuk, V.N.; Bazai, A.V.; Goryainov, P.M.; Ivanyuk, G.Y. 3D mineralogical mapping of the Kovdor phoscorite-carbonatite complex (Russia). Miner. Depos. 2016, 51, 131-149. [CrossRef]

24. Kalashnikov, A.O.; Ivanyuk, G.Y.; Mikhailova, J.A.; Sokharev, V.A. Approach of automatic 3D geological mapping: The case of the Kovdor phoscorite-carbonatite complex, NW Russia. Sci. Rep. 2017, 7, 6893. [CrossRef] [PubMed]

25. Kalashnikov, A.O.; Konopleva, N.G.; Pakhomovsky, Y.A.; Ivanyuk, G.Y. Rare earth deposits of the Murmansk Region, Russia-A review. Econ. Geol. 2016, 111, 1529-1559. [CrossRef]

26. Ivanyuk, G.; Kalashnikov, A.; Pakhomovsky, Y.; Bazai, A.; Goryainov, P.; Mikhailova, J.; Yakovenchuk, V.; Konopleva, N. Subsolidus Evolution of the Magnetite-Spinel-UlvöSpinel Solid Solutions in the Kovdor Phoscorite-Carbonatite Complex, NW Russia. Minerals 2017, 7, 215. [CrossRef]

27. Ivanyuk, G.Y.; Kalashnikov, A.O.; Pakhomovsky, Y.A.; Mikhailova, J.A.; Yakovenchuk, V.N.; Konopleva, N.G.; Sokharev, V.A.; Bazai, A.V.; Goryainov, P.M. Economic minerals of the Kovdor baddeleyite-apatite-magnetite deposit, Russia: Mineralogy, spatial distribution and ore processing optimization. Ore Geol. Rev. 2016, 77, 279-311. [CrossRef]

28. Kalashnikov, A.O.; Yakovenchuk, V.N.; Pakhomovsky, Y.A.; Bazai, A.V.; Sokharev, V.A.; Konopleva, N.G.; Mikhailova, J.A.; Goryainov, P.M.; Ivanyuk, G.Y. Scandium of the Kovdor baddeleyite-apatite-magnetite deposit (Murmansk Region, Russia): Mineralogy, spatial distribution, and potential resource. Ore Geol. Rev. 2016, 72, 532-537. [CrossRef]

29. Ivanyuk, G.Y.; Pakhomovsky, Y.A.; Panikorovsky, T.L.; Mikhailova, J.A.; Kalashnikov, A.O.; Bazai, A.V.; Yakovenchuk, V.N.; Konopleva, N.G.; Goryainov, P.M. Three-D Mineralogical Mapping of the Kovdor Phoscorite-Carbonatite Complex, NW Russia: III. Pyrochlore Supergroup Minerals. Minerals 2018, 8, 277. [CrossRef]

30. Krivovichev, S.V.; Yakovenchuk, V.N.; Zhitova, E.S.; Zolotarev, A.A.; Pakhomovsky, Y.A.; Ivanyuk, G.Y. Crystal chemistry of natural layered double hydroxides. 1. Quintinite-2H-3c from the Kovdor alkaline massif, Kola peninsula, Russia. Mineral. Mag. 2010, 74, 821-832. [CrossRef] 
31. Krivovichev, S.V.; Yakovenchuk, V.N.; Zhitova, E.S.; Zolotarev, A.A.; Pakhomovsky, Y.A.; Ivanyuk, G.Y. Crystal chemistry of natural layered double hydroxides. 2. Quintinite-1M: First evidence of a monoclinic polytype in M2+-M3+ layered double hydroxides. Mineral. Mag. 2010, 74, 833-840. [CrossRef]

32. Zhitova, E.S.; Yakovenchuk, V.N.; Krivovichev, S.V.; Zolotarev, A.A.; Pakhomovsky, Y.A.; Ivanyuk, G.Y. Crystal chemistry of natural layered double hydroxides. 3. The crystal structure of $\mathrm{Mg}, \mathrm{Al}$-disordered quintinite-2H. Mineral. Mag. 2010, 74, 841-848. [CrossRef]

33. Zhitova, E.S.; Ivanyuk, G.Y.; Krivovichev, S.V.; Yakovenchuk, V.N.; Pakhomovsky, Y.A.; Mikhailova, Y.A. Crystal Chemistry of Pyroaurite from the Kovdor Pluton, Kola Peninsula, Russia, and the Långban Fe-Mn deposit, Värmland, Sweden. Geol. Ore Depos. 2017, 59, 652-661. [CrossRef]

34. Zhitova, E.S.; Krivovichev, S.V.; Yakovenchuk, V.N.; Ivanyuk, G.Y.; Pakhomovsky, Y.A.; Mikhailova, J.A. Crystal chemistry of natural layered double hydroxides. 4. Crystal structures and evolution of structural complexity of quintinite polytypes from the Kovdor alkaline massif, Kola peninsula, Russia. Mineral. Mag. 2018, 82, 329-346. [CrossRef]

35. Yakovenchuk, V.N.; Ivanyuk, G.Y.; Mikhailova, Y.A.; Selivanova, E.A.; Krivovichev, S.V. Pakhomovskyite, $\mathrm{Co}_{3}\left(\mathrm{PO}_{4}\right)_{2} \cdot 8 \mathrm{H}_{2} \mathrm{O}$, a new mineral species from Kovdor, Kola Peninsula, Russia. Can. Mineral. 2006, 44, 117-123. [CrossRef]

36. Yakovenchuk, V.N.; Ivanyuk, G.Y.; Pakhomovsky, Y.A.; Panikorovskii, T.L.; Britvin, S.N.; Krivovichev, S.V.; Shilovskikh, V.V.; Bocharov, V.N. Kampelite, $\mathrm{Ba}_{3} \mathrm{Mg}_{1.5} \mathrm{Sc}_{4}\left(\mathrm{PO}_{4}\right)_{6}(\mathrm{OH})_{3} \cdot 4 \mathrm{H}_{2} \mathrm{O}$, a new very complex Ba-Sc phosphate mineral from the Kovdor phoscorite-carbonatite complex (Kola Peninsula, Russia). Mineral. Petrol. 2017, 4, 111-121. [CrossRef]

37. Tomilin, M.G.; Ivanyuk, G.Y. The application of thin nematic liquid crystal layers to mineral analysis. Liq. Cryst. 1993, 14, 1599-1606. [CrossRef]

38. UTHSCSA. ImageTool 3.0. Available online: http://www.compdent.uthscsa.edu/dig/pub/IT (accessed on 8 July 2013).

39. Rosstandart FR.1.31.2016.25424. The Method for Determining the Content of Rare-Earth Elements (Y, La, Ce, $\mathrm{Pr}, \mathrm{Nd}, \mathrm{Sm}, \mathrm{Eu}, \mathrm{Gd}, \mathrm{Tb}, \mathrm{Dy}, \mathrm{Ho}, \mathrm{Er}, \mathrm{Tm}, \mathrm{Yb}, \mathrm{Lu})$, Sodium, Aluminum, Potassium, Calcium, Titanium, Iron, Thorium and Uranium in Apatite Mineral Raw Materials and Phosphogypsum by Inductively Coupled Plasma Mass Spectrometry. Available online: http:/ / www.fundmetrology.ru/06_metod/2view_file.aspx? id=25424 (accessed on 27 June 2018).

40. Dolivo-Dobrovolsky, D.D. MINAL, Free Software. Available online: http://www.dimadd.ru (accessed on 8 July 2013).

41. StatSoft Inc. Statistica 8. Available online: www.statsoft.ru (accessed on 27 June 2018).

42. Systat Software Inc. TableCurve 2D. Available online: www.sigmaplot.co.uk/products/tablecurve2d/ tablecurve2d.php (accessed on 19 June 2018).

43. Micromine Pty Ltd. Micromine 16.1. Available online: www.micromine.com (accessed on 27 June 2018).

44. Sheldrick, G.M. A short history of SHELX. Acta Crystallogr. Sect. A Found. Crystallogr. 2008, 64, 112-122. [CrossRef] [PubMed]

45. Dolomanov, O.V.; Bourhis, L.J.; Gildea, R.J.; Howard, J.A.K.; Puschmann, H. OLEX2: A complete structure solution, refinement and analysis program. J. Appl. Crystallogr. 2009, 42, 339-341. [CrossRef]

46. Agilent CrysAlis PRO 2014. Available online: https://www.rigaku.com/en/products/smc/crysalis (accessed on 19 June 2018).

47. Putz, H.; Brandenburg, K. Diamond-Crystal and Molecular Structure Visualization; Crystal Impact GbR: Bonn, Germany, 2012.

48. De Villiers, J.P.R.; Liles, D.C. The crystal-structure and vacancy distribution in 6C pyrrhotite. Am. Mineral. 2010, 95, 148-152. [CrossRef]

49. International Tables for Crystallography. Volume C: Mathematical, Physical and Chemical Tables; Wilson, A.J.C. (Ed.) Kluwer Academic: Dordrecht, The Netherlands, 1992.

50. Alsén, N. Röntgenographische Untersuchung der Kristallstrukturen von Magnetkies, Breithauptit, Pentlandit, Millerit und verwandten Verbindungen. Geologiska Föreningen i Stockholm Förhandlingar 1925, 47, 19-72. [CrossRef]

51. Tokonami, M.; Nishiguchi, K.; Morimoto, N. Crystal structure of a monoclinic pyrrhotite (Fe7S8). Am. Mineral. 1972, 57, 1066-1080. 
52. Morimoto, N.; Gyobu, A.; Mukaiyama, H.; Izawa, E. Crystallography and stability of pyrrhotites. Econ. Geol. 1975, 70, 824-833. [CrossRef]

53. De Villiers, J.P.R.; Liles, D.C.; Becker, M. The crystal structure of a naturally occurring 5C pyrrhotite from Sudbury, its chemistry, and vacancy distribution. Am. Mineral. 2009, 94, 1405-1410. [CrossRef]

54. Koto, K.; Morimoto, N.; Gyobu, A. The superstructure of the intermediate pyrrhotite. I. Partially disordered distribution of metal vacancy in the $6 \mathrm{C}$ type, Fe $11 \mathrm{~S} 12$. Acta Crystallogr. Sect. B Struct. Crystallogr. Cryst. Chem. 1975, 31, 2759-2764. [CrossRef]

55. Yamamoto, A.; Nakazawa, H. Modulated structure of the NC-type $(\mathrm{N}=5.5)$ pyrrhotite, $\mathrm{Fe}_{1-\mathrm{x}} \mathrm{S}$. Acta Crystallogr. Sect. A 1982, 38, 79-86. [CrossRef]

56. De Villiers, J. The Composition and Crystal Structures of Pyrrhotite: A Common but Poorly Understood Mineral. Available online: http:/ / www.mintek.co.za/Mintek75/Proceedings/L01-DeVilliers.pdf (accessed on 19 June 2018).

57. Liles, D.C.; de Villiers, J.P.R. Redetermination of the structure of 5C pyrrhotite at low temperature and at room temperature. Am. Mineral. 2012, 97, 257-261. [CrossRef]

58. Kaneda, H.; Takenouchi, S.; Shoji, T. Stability of pentlandite in the Fe-Ni-Co-S system. Miner. Depos. 1986, 21, 169-180. [CrossRef]

59. Barton, P.B.; Toulmin, P. Phase relations involving sphalerite in the Fe-Zn-S system. Econ. Geol. 1966, 61, 815-849. [CrossRef]

60. Lusk, J.; Ford, C.E. Experimental extension of the sphalerite geobarometer to 10 kbar. Am. Mineral. 1978, 63, 516-519.

61. Scott, S.D.; Barnes, H.L. Sphalerite geothermometry and geobarometry. Econ. Geol. 1971, 66, 653-669. [CrossRef]

62. Fleet, M.E.M.E. Phase Equilibria at High Temperatures. Rev. Mineral. Geochem. 2006, 61, 365-419. [CrossRef]

63. Ghiorso, M.S.; Evans, B.W. Thermodynamics of rhombohedral oxide solid solutions and a revision of the Fe-Ti two-oxide geothermometer and oxygen-barometer. Am. J. Sci. 2008, 308, 957-1039. [CrossRef]

64. Yund, R.A.; Hall, H.T. Kinetics and Mechanism of Pyrite Exsolution from Pyrrhotite. J. Petrol. 1970, 11, 381-404. [CrossRef]

65. Kissin, S.A.; Scott, S.D. Phase relations involving pyrrhotite below 350 degrees C. Econ. Geol. 1982, 77, 1739-1754. [CrossRef]

66. Nekrasov, I.J.; Besmen, N.I. Pyrite-pyrrhotite geothermometer. Distribution of cobalt, nickel and tin. Phys. Chem. Earth 1979, 11, 767-771. [CrossRef]

67. Lusk, J.; Scott, S.D.; Ford, C.E. Phase relations in the Fe-Zn-S system to 5 kbars and temperatures between 325 degrees and 150 degrees C. Econ. Geol. 1993, 88, 1880-1903. [CrossRef]

68. Kapustin, Y. Mineralogy of the Weathering Crust of Carbonatites; Nedra: Moscow, Russia, 1973. (In Russian)

69. Liferovich, R.P.; Pakhomovsky, Y.A.; Yakovenchuk, V.N.; Bogdanova, A.N.; Bakhchisaraitsev, A.Y. Vivianite minerals group and bobierrite from the Kovdor massif. Zap. RMO 1999, 128, 109-117.

70. Liferovich, R.P.; Sokolova, E.V.; Hawthorne, F.C.; Laajoki, K.V.O.; Gehor, S.; Pakhomovsky, Y.A.; Sorokhtina, N.V. Gladiusite, $\mathrm{Fe}^{3+}{ }_{2}\left(\mathrm{Fe}^{2+}, \mathrm{Mg}\right)_{4}\left(\mathrm{PO}_{4}\right)(\mathrm{OH})_{11}\left(\mathrm{H}_{2} \mathrm{O}\right)$, a new hydrothermal mineral species from the phoscorite carbonatite unit, Kovdor complex, Kola Peninsula, Russia. Can. Mineral. 2000, 38, 1477-1485. [CrossRef]

71. Doyle, C.D.; Naldrett, A.J. Ideal mixing of divalent cations in mafic magma. II. The solution of $\mathrm{NiO}$ and the partitioning of nickel between coexisting olivine and liquid. Geochim. Cosmochim. Acta 1987, 51, $213-219$. [CrossRef]

72. Seifert, S.; O'Neill, H.S.C.; Brey, G. The partitioning of Fe, Ni and Co between olivine, metal, and basaltic liquid: An experimental and thermodynamic investigation, with application to the composition of the lunar core. Geochim. Cosmochim. Acta 1988, 52, 603-616. [CrossRef]

73. Ehlers, K.; Grove, T.L.; Sisson, T.W.; Recca, S.I.; Zervas, D.A. The effect of oxygen fugacity on the partitioning of nickel and cobalt between olivine, silicate melt, and metal. Geochim. Cosmochim. Acta 1992, 56, 3733-3743. [CrossRef]

74. Li, C.; Ripley, E.M.; Mathez, E.A. The effect of S on the partitioning of Ni between olivine and silicate melt in MORB. Chem. Geol. 2003, 201, 295-306. [CrossRef] 
75. Gaetani, G.A.; Grove, T.L. Partitioning of moderately siderophile elements among olivine, silicate melt, and sulfide melt: Constraints on core formation in the Earth and Mars. Geochim. Cosmochim. Acta 1997, 61, 1829-1846. [CrossRef]

76. Kiseeva, E.S.; Wood, B.J. A simple model for chalcophile element partitioning between sulphide and silicate liquids with geochemical applications. Earth Planet. Sci. Lett. 2013, 383, 68-81. [CrossRef]

77. Li, Y.; Audétat, A. Effects of temperature, silicate melt composition, and oxygen fugacity on the partitioning of $\mathrm{V}, \mathrm{Mn}, \mathrm{Co}, \mathrm{Ni}, \mathrm{Cu}, \mathrm{Zn}, \mathrm{As}, \mathrm{Mo}, \mathrm{Ag}, \mathrm{Sn}, \mathrm{Sb}, \mathrm{W}, \mathrm{Au}, \mathrm{Pb}$, and Bi between sulfide phases and silicate melt. Geochim. Cosmochim. Acta 2015, 162, 25-45. [CrossRef]

78. Powell, A.V.; Vaqueiro, P.; Knight, K.S.; Chapon, L.C.; Sánchez, R.D. Structure and magnetism in synthetic pyrrhotite Fe7S8: A powder neutron-diffraction study. Phys. Rev. B 2004, 70, 014415. [CrossRef]

79. Krivovichev, S.V. Topological complexity of crystal structures: Quantitative approach. Acta Crystallogr. Sect. A Found. Crystallogr. 2012, 68, 393-398. [CrossRef] [PubMed]

80. Krivovichev, S.V. Structural complexity of minerals: Information storage and processing in the mineral world. Mineral. Mag. 2013, 77, 275-326. [CrossRef]

81. Holzheid, A.; Palme, H. The influence of FeO on the solubilities of cobalt and nickel in silicate melts. Geochim. Cosmochim. Acta 1996, 60, 1181-1193. [CrossRef]

82. Keppler, H. Water solubility in carbonatite melts. Am. Mineral. 2003, 88, 1822-1824. [CrossRef]

83. Zhong, R.; Brugger, J.; Chen, Y.; Li, W. Contrasting regimes of $\mathrm{Cu}, \mathrm{Zn}$ and $\mathrm{Pb}$ transport in ore-forming hydrothermal fluids. Chem. Geol. 2015, 395, 154-164. [CrossRef]

84. Leroy, A. Palabora-Not just another copper mine. Miner. Ind. Int. 1992, 1005, 14-19.

85. Palabora_Mining_Company_Limited. The geology and the economic deposits of copper, iron, and vermiculite in the Palabora igneous complex: A brief review. Econ. Geol. 1976, 71, 177-192.

86. Vielreicher, N.M.; Groves, D.I.; Vielreicher, R.M. The Phalaborwa (Palabora) Deposit and its Potential Connection to Iron-Oxide Copper-Gold Deposits of Olympic Dam Type. In Hydrothermal Iron Oxide Copper-Gold E Related Deposits: A Global Perspective, Volume 1; Porter, T.M., Ed.; PGS Publishing: Adelaide, Australia, 2000; pp. 321-329.

87. Karchevsky, P.I. Sulfide, Strontium, and REE Mineralozation in Phoscorites and Carbonatites of the Turiy Complex (Russia) and Loolekop Deposit (RSA); Kolo: St. Petersburg, Russia, 2005.

88. Verwoerd, W. Mineral deposits associated with carbonatites and alkaline rocks. In Mineral Deposits of Southern Africa. Volume 2; Anhaeusser, C.R., Maske, S., Eds.; Geological Society of South Africa: Johannesburg, South Africa, 1986; pp. 2173-2191.

89. Ericsson, S. Phalaborwa: A saga of magmatism, metasomatism and miscibility. In Carbonatites: Genesis and Evolution; Bell, K., Ed.; Unwin Hyman: London, UK, 1989; pp. 221-250.

90. Heinrich, E. The Palabora Carbonatitic Complex-A Unique Copper Deposit. Can. Mineral. 1970, 10, 585-598.

91. Gaillard, F.; Scaillet, B.; Pichavant, M.; Bény, J.-M. The effect of water and $\mathrm{fO}_{2}$ on the ferric-ferrous ratio of silicic melts. Chem. Geol. 2001, 174, 255-273. [CrossRef]

92. Wilke, M.; Behrens, H.; Burkhard, D.J.; Rossano, S. The oxidation state of iron in silicic melt at 500 MPa water pressure. Chem. Geol. 2002, 189, 55-67. [CrossRef]

93. Schuessler, J.A.; Botcharnikov, R.E.; Behrens, H.; Misiti, V.; Freda, C. Amorphous Materials: Properties, structure, and Durability: Oxidation state of iron in hydrous phono-tephritic melts. Am. Mineral. 2008, 93, 1493-1504. [CrossRef]

94. Richards, J.P. The oxidation state, and sulfur and $\mathrm{Cu}$ contents of arc magmas: Implications for metallogeny. Lithos 2014, 233, 27-45. [CrossRef]

95. Groves, D.I.; Vielreicher, N.M. The Phalabowra (Palabora) carbonatite-hosted magnetite-copper sulfide deposit, South Africa: An end-member of the iron-oxide copper-gold-rare earth element deposit group? Miner. Depos. 2001, 36, 189-194. [CrossRef]

(C) 2018 by the authors. Licensee MDPI, Basel, Switzerland. This article is an open access article distributed under the terms and conditions of the Creative Commons Attribution (CC BY) license (http://creativecommons.org/licenses/by/4.0/). 